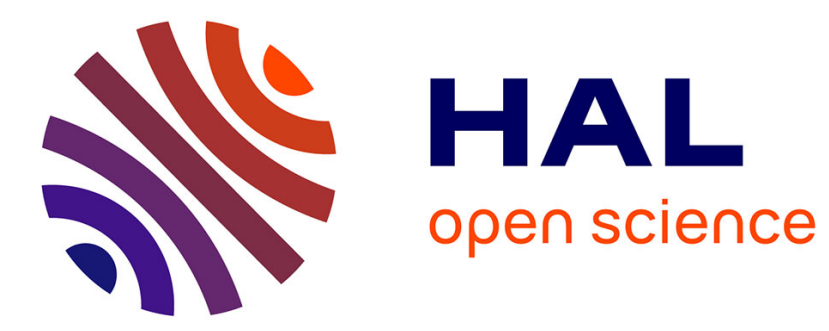

\title{
Scleractinian coral population size structures and growth rates indicate coral resilience on the fringing reefs of North Jamaica
}

\author{
M. James C. Crabbe
}

\section{- To cite this version:}

M. James C. Crabbe. Scleractinian coral population size structures and growth rates indicate coral resilience on the fringing reefs of North Jamaica. Marine Environmental Research, 2009, 67 (4-5), pp.189. 10.1016/j.marenvres.2009.01.003 . hal-00482199

\section{HAL Id: hal-00482199 \\ https://hal.science/hal-00482199}

Submitted on 10 May 2010

HAL is a multi-disciplinary open access archive for the deposit and dissemination of scientific research documents, whether they are published or not. The documents may come from teaching and research institutions in France or abroad, or from public or private research centers.
L'archive ouverte pluridisciplinaire HAL, est destinée au dépôt et à la diffusion de documents scientifiques de niveau recherche, publiés ou non, émanant des établissements d'enseignement et de recherche français ou étrangers, des laboratoires publics ou privés. 


\section{Accepted Manuscript}

Scleractinian coral population size structures and growth rates indicate coral resilience on the fringing reefs of North Jamaica

M. James C. Crabbe

PII:

S0141-1136(09)00017-8

DOI:

10.1016/j.marenvres.2009.01.003

Reference:

MERE 3316

To appear in:

Marine Environmental Research

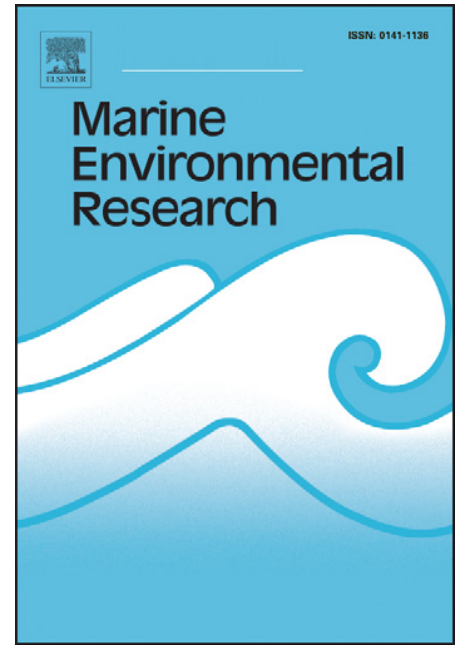

Received Date: $\quad 26$ August 2008

Revised Date: $\quad 18$ January 2009

Accepted Date: $\quad 30$ January 2009

Please cite this article as: C. Crabbe, M.J., Scleractinian coral population size structures and growth rates indicate coral resilience on the fringing reefs of North Jamaica, Marine Environmental Research (2009), doi: 10.1016/ j.marenvres.2009.01.003

This is a PDF file of an unedited manuscript that has been accepted for publication. As a service to our customers we are providing this early version of the manuscript. The manuscript will undergo copyediting, typesetting, and review of the resulting proof before it is published in its final form. Please note that during the production process errors may be discovered which could affect the content, and all legal disclaimers that apply to the journal pertain. 
1 Scleractinian coral population size structures and growth rates indicate coral resilience

2

3

4

5

6

7

8

9

10

11

12

13 Keywords: demographics; tropical storms; hurricanes; cyclones; bleaching; climate 14 on the fringing reefs of North Jamaica.

\author{
M. James C. Crabbe*
}

Institute for Research in the Applied Natural Sciences,

Faculty of Creative Arts, Technologies and Science, University of Bedfordshire, Park Square, Luton, LU1 3JU, U.K

*Corresponding author: MJC Crabbe: email: james.crabbe@beds.ac.uk; Tel: +44 (0) 1582489265; Fax: +44 (0) 1582489212 change; global warming; coral growth; recruitment, Discovery Bay 


\section{ACCEPTED MANUSCRIPT}

1 Abstract

2 Coral reefs throughout the world are under severe challenges from many

3 environmental factors. This paper quantifies the size-structure of populations and the

4 growth rates of corals from 2000-2008 to test whether the Discovery Bay coral

5 colonies showed resilience in the face of multiple acute stressors of hurricanes and

6 bleaching. There was a reduction in numbers of colonies in the smallest size class for

7 all the species at all the sites in 2006, after the mass bleaching of 2005, with

8 subsequent increases for all species at all sites in 2007 and 2008. Radial growth rates

9 (mm/yr) of non-branching corals and linear extension rates (mm/yr) of branching

10 corals calculated on an annual basis from 2000-2008 showed few significant

11 differences either spatially or temporally. At Dairy Bull reef, live coral cover

12 increased from $13 \pm 5 \%$ in 2006 to $20 \pm 9 \%$ in 2007 and $31 \pm 7 \%$ in 2008, while live

13 Acropora species increased from $2 \pm 2 \%$ in 2006 to $10 \pm 4 \%$ in 2007 and $22 \pm 7 \%$ in

14 2008. These studies indicate good levels of coral resilience on the fringing reefs

15 around Discovery Bay in Jamaica.

16

17

18

19 
1

2

8 one of the best documented areas of reef decline in the Caribbean, where loss of

9 corals and macroalgal domination has been due to hurricanes (Woodley et al., 1981,

10 Crabbe et al., 2002), overfishing (Jackson, 1997; Hawkins and Roberts, 2004), die-off

11 of the long-spined sea urchin Diadema antillarum in 1983-84 (Hughes, 1994), and

12 coral disease (Aronson and Precht, 2001). Nutrient enrichment does not appear to

13 have been a causal factor in the development of the reef macroalgal communities

14 (Greenaway and Gordon-Smith, 2006).

$$
\text { Maintaining coral reef populations in the face of large scale }
$$
degradation and phase-shifts on reefs depends critically on recruitment (Hughes and Tanner, 2000; Coles and Brown, 2007), maintenance of grazing fish and urchin populations (Mumby at al., 2007), clade of symbiotic zooxanthellae (Stat et al., 2008) and management of human activities related to agricultural land use and coastal development (Mora, 2008). To manage coral reefs it is important to have an understanding of coral population demography - structure and dynamics (Soong, 1993, Meesters et al., 2001; Smith et al., 2005). Ideally, this involves the quantification of numbers of individual colonies of different size classes - the population structure- through time, in addition to quantifying coral growth rates, recruitment and survival. The fringing reefs around Discovery Bay have seen a 
1 number of climate-related challenges in recent years, notably several hurricanes as

2 well as a mass bleaching event in the Caribbean in 2005 (Jones et al., 2004; 2008).

3 Despite all these negative factors, there is evidence that prior to 2005 some Discovery

4 Bay reefs were recovering (Idjadi et al., 2008), although a study subsequent to the

52005 bleaching event is not so positive (Quinn and Kojis, 2008). Healthy reefs have a

6 high proportion of small size-classes that include new recruits and juveniles (Meesters

7 et al., 2001), and the smallest size class of corals can be a good indicator of reef

8 resilience (Loya, 1976; Connell, 1978). This study set out to quantify the size-

9 structure of populations and the growth rates of a number of corals over time in order

10 to test whether the Discovery Bay coral colonies were exhibiting resilience in the face

11 of multiple acute stressors of hurricanes and bleaching. I take the definition of

12 resilience as the ability of the system to recover from disturbance and change, while

13 maintaining its function (Carpenter et al, 2001; Grimsditch and Salm, 2006); for

14 example a coral reef's ability to recover from a bleaching event. Resilience is a multi-

15 faceted concept (Nyström et al., 2008), and factors that can improve coral reef

16 resilience to a mass bleaching event include good species and functional diversity,

17 good connectivity to larval sources, appropriate substrates for larval settlement and

18 protection from other anthropogenic impacts.

\section{2. Methods}

2.1. Data on storms, hurricanes and bleaching events impacting Discovery

22 Bay

23 Data on storm severity as it impacted the Discovery Bay sites was obtained from

24 UNISYS (http://weather.unisys.com/hurricane/atlantic/) and the NOAA hurricane site

25 (http://www.nhc.noaa.gov/pastall.shtml). 
2 (http://coralreefwatch.noaa.gov/satellite/current/sst_series_24reefs.html) and from

3 Jones et al. (2008).

4

\section{$5 \quad$ 2.2. Sites and Sampling}

6 Four haphazardly located transects, each $15 \mathrm{~m}$ long and separated by at least $5 \mathrm{~m}$, were

7 laid at between 5-8.5 m depth at each of five sites [Rio Bueno $\left(18^{\circ} 28.805^{\prime} \mathrm{N}\right.$; $77^{\circ}$

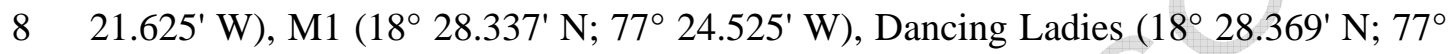

$924.802^{\prime}$ W), Dairy Bull (18 28.083' N; $77^{\circ} 23.302^{\prime}$ W) and Pear Tree Bottom (18

$\left.1027.829^{\prime} \mathrm{N} ; 7^{\circ} 21.403^{\prime} \mathrm{W}\right)$ ] along the fringing reefs surrounding Discovery Bay,

11 Jamaica (Fig. 1). GPS coordinates were determined using a hand-held GPS receiver

12 (Garmin Ltd.). Corals 2m either side of the transect lines were photographed for 13 archive information, and surface areas measured with flexible tape as described 14 previously using SCUBA (Crabbe et al., 2002; Crabbe and Smith 2005; Crabbe et al., 15 2008). For non-branching corals, this was done by measuring the widest diameter of 16 the coral and the diameter at $90^{\circ}$ to that. For branching corals (Acropora palmata and 17 Acropora cervicornis), linear extension rates were measured using digital 18 photography and image analysis, validated by measurements with flexible tape 19 (Crabbe et al., 2002; Crabbe and Smith, 2005). Depth of samples was between 5-8.5 $20 \mathrm{~m}$, to minimise variation in growth rates due to depth (Huston, 1985). To increase 21 accuracy, surface areas rather than diameters of live non-branching corals were 22 measured (Crabbe et al., 2002; Crabbe and Smith, 2005). Sampling was over as wide 23 a range of sizes as possible. Colonies that were close together $(<50 \mathrm{~mm})$ or touching 24 were avoided to minimise age discontinuities through fission and altered growth rates 25 (Hughes and Jackson, 1980; Foster et al., 2007; Elahi and Edmunds, 2007). 
In this study we ignored Montastrea annularis colonies, because their surface

2 area does not reflect their age (Hughes and Jackson 1980), and because hurricanes can

3 increase their asexual reproduction through physical damage (Foster et al., 2007).

4
Radial growth rates of non-branching corals and linear extension rates of branching corals were calculated for each year from 2000-2008 as described previously (Crabbe et al., 2002; Crabbe and Smith, 2005). Overall, over 8,000 measurements were made on over 1,500 coral colonies, equally distributed between the sites for species and numbers of colonies.

This work was conducted at Discovery Bay during July 15-31 and December 19-30 in 2000, March 26 - April 19 in 2002, March 18 - April 10 in 2003, July 23 August 21 in 2004, July 18 - August 13 in 2005, April 11- 18 in 2006, December 30 in 2006 - January 6 in 2007, and July 30 - August 16 in 2008. Surveys were made at the same locations at the same sites each year.

Computer digital image analysis for coral linear extension rates was undertaken using the UTHSCSA (University of Texas Health Science Center, San Antonio, Texas, USA) Image Tool software (Crabbe and Smith, 2005). One or twofactor ANOVA was used to compare coral data among sites; \pm error values represent standard errors of the data. The skewness coefficient (sk) (Zar, 1999) was used to quantify the relationship between the number of large and small corals within each population. The skewness for a normal distribution about the mean is zero, and any symmetric data should have a skewness near zero. Negative values for the skewness indicate data that are skewed left (more small colonies than in a normal distribution) and positive values for the skewness indicate data that are skewed right (more large colonies than in a normal distribution). Water quality measurements at the sites have been reported previously (D’Elia et al., 1981; Greenaway and Gordon-Smith, 2006). 


\section{RESULTS}

4

\subsection{Environmental climate stressors- tropical storms and bleaching events}

Hurricanes that had the potential to impact the reef sites during the study period are shown in Fig. 2, with their paths of travel. Only one of these storms resulted in any significant damage on the reefs, Ivan in 2004, a category 4 hurricane as it passed south of the island. Visually, the damage was minimal as far as reef destruction was concerned, with some A. palmata colonies being fragmented and overturned, notably at Pear Tree Bottom (personal observation). Although hurricane Emily in 2005 was also a category 4 hurricane, the eye passed sufficiently south of the island so that the impact involved sediment transfer owing to the high winds and rain (Crabbe and Carlin 2007). Tropical storms Iris (category 1 hurricane, 2001), Lili (tropical storm, 2002), Bonnie (tropical wave, 2004), Charley (category 1 hurricane, 2004), Dennis (category 3 hurricane, 2005), Olga (tropical storm, 2007) and Dean (hurricane category 4, 2007) did not result in significant damage to the reef sites.

The only bleaching event that significantly impacted the reef sites during the study period was the mass Caribbean bleaching event of 2005. Analysis of satellite data showed that there were 6 degree heating weeks (dhw) for sea surface temperatures in September and October 2005 near Discovery Bay, data which was mirrored by data loggers on the reefs (Quinn and Kojis, 2008). Six dhw are equivalent to six weeks of sea surface temperatures (SSTs) one degree Celsius greater than the expected summer maximum.

\subsection{Coral colony size-frequency distributions and growth rates}


Fig 3 a-h compares the size-frequency distribution of the corals Sidastrea

2 siderea, Diploria labyrinthiformis, Porites astreoides, and Colpophyllia natans at the

3 fringing reef sites Rio Bueno, M1, Dancing Ladies, Dairy Bull, and Pear Tree Bottom

4 in 2002 and 2008. These dates covered the major bleaching event and hurricane Ivan.

5 Size-frequency distributions were also determined for the corals Diploria strigosa

6 Meandrina meandrites, and Agaricia species, and the results discussed below. All the

7 sites showed some similarities in distribution of the size classes for the species studied

8 between 2002 and 2008. However, there were differences between the different sites,

9 and between the different species studied at the sites. Skewness values (sk) were used

10 to compare the distribution of the data between 2002 and 2008. For S. siderea, all sk

11 values were positive (skewed to the left, with more large colonies than in a normal

12 distribution) for 02 and 08, with little change between the dates (all sk values between

$13 \quad 0.5$ and 1.6). With $D$. labyrinthiformis colonies, there was a change from negative

14 skewness in 2002 at Dairy Bull and Pear Tree Bottom (skewed to the right, with more

15 small colonies than in a normal distribution) (sk values -0.25 and -0.006 respectively)

16 to more larger colonies than in a normal distribution in 2008 (sk values of 0.20 and

170.97 respectively). There were no significant changes from 2002-2008 at the other

18 sites, with positive sk values from 0.1 to 0.89 . M. meandrites colonies at Rio Bueno

19 and Dairy Bull showed a relative decrease in the distribution of smaller colonies from

202002 to 2008 , with changes in sk values from -0.03 in 02 to 0.78 in 08 , and from -0.05

21 to 0.03 respectively; the other sites all exhibited slightly positive sk values in both

22 years from between 0.1 to 0.5 . For Agaricia species, there was very little change

23 between the years at all the sites, with sk values from between 0.4 to 1.6. For $P$.

24 astreoides, all values were positive for both years, with an increase in skewness at Rio

25 Bueno from 0.2 to 2.6, showing a marked change in distribution towards the larger 
1 colony sizes. At the other sites there were only small increases in sk values from 2002

2 to 2008, with Pear tree Bottom showing a decrease in skewness from 0.9 to 0.6. $D$.

3 strigosa colonies showed similar results to P. astreoides, all sk values being positive

4 for 2002 and 2008, with an increase at Rio Bueno from 0.2 to 2.2 and at Pear Tree

5 Bottom from 0.4 to 2.4; other sites showed similar sk values for 2002 and 2008 from

$6 \quad 0.6$ to 1.6. C. natans skewness changed from -0.07 to 0.68 at Rio Bueno from 2002

7 to 2008 (a decrease in smaller colonies relative to a normal distribution), and at

8 Dancing Ladies from -0.31 to 0.38 . Other sites showed similar skewness in 2002 and

92008 (sk values between 0.5-0.6), except Pear Tree Bottom, which exhibited near

10 normal distribution of colonies about the mean for both 2002 and 2008 (sk values

11 <.01). There was no correlation between coral size-frequency distributions and

12 water quality, (taken from Greenaway and Gordon-Smith, 2006).

13 As by far the major disturbance to the reef sites was the mass bleaching event

14 of 2005, the mean size class for all the species at all the reef sites were compared for

15 2002, 2006 (after the bleaching event) and 2008, with examples shown in Fig. 4a-d.

16 For S. siderea colonies mean size class was lower in 2006 than in 2002 at all sites

$17(\mathrm{~F}>1.5, \mathrm{p}<0.01)$ except at Dancing Ladies where there was no significant difference.

18 Mean size class was raised from 2006 to 2008 at all sites ( $\mathrm{f}>5, \mathrm{p}<0.001$ ) except at Rio

19 Bueno (no significant difference) and at Pear Tree Bottom (lower mean size class,

$20 \mathrm{~F}>2, \mathrm{p}<0.02$ ). There were no significant differences in mean size class between 2002

21 and 2008 except at Rio Bueno, where it was lower $(\mathrm{F}>1.5, \mathrm{p}<0.02)$. For $D$.

22 labyrinthiformis colonies, there were significant reductions in mean size class from

232002 to 2006 at Dairy Bull and Pear Tree Bottom (both F>2, p<0.03) and reductions

24 at M1 and Pear Tree Bottom from 2002 to $2008(\mathrm{~F}>3, \mathrm{p}<0.01$ and $\mathrm{F}>1.5, \mathrm{p}<0.05$

25 respectively). There were no significant increases in size class from 2006 to 2008. 
1 This was also the case for M. meandrites colonies, where there were no significant

2 changes in mean size class between the years. In contrast, there were significant

3 reductions in mean size class of Agaricia species mean size class at all sites from

42002 to $2006(\mathrm{~F}>4, \mathrm{p}<0.01)$, and mean size class was significantly higher from 2006

5 to 2008 at all sites ( $\mathrm{F}>2, \mathrm{p}<0.03$ for Rio Bueno, $\mathrm{F}>6, \mathrm{p}<0.008$ for other sites). Mean

6 size class was only significantly lower in 2008 than in 2002 at Dairy Bull ( $F>2$,

$7 \quad \mathrm{p}<0.01)$. Mean class size of $P$. astreoides colonies had reduced significantly from

82002 to 2006 only at Dancing Ladies and Dairy Bull (F>2, $<<0.01$ for both), and

9 reduced significantly from 2006 to 2008 at Rio Bueno $(\mathrm{F}>2, \mathrm{p}<0.03)$. All sites had

10 reduced significantly from 2002 to 2008 (F>4, p<0.01) except Pear Tree Bottom (not

11 significant). For D. strigosa, mean size class had reduced from 2002 to 2006 at

12 Dancing Ladies, Dairy Bull and Pear Tree Bottom (all $\mathrm{F}>1.5, \mathrm{p}<0.04$ ), and had

13 reduced again in 2008 at Rio Bueno, Dairy Bull and Pear Tree Bottom (all F>5,

$14 \mathrm{p}<0.002)$; mean size class was lower at all sites in 2008 than in $2002(\mathrm{~F}>4, \mathrm{p}<0.005)$

15 for this species. For $C$. natans, mean size class fell significantly $(F>4, p<0.01)$ at all

16 sites except at Rio Bueno (no significant difference) from 2002 to 2006. From 2006 to

17 2008, mean size class was raised at Dairy Bull and at Pear Tree Bottom (both F>5,

$18 \mathrm{p}<0.01)$ but fell at Rio Bueno and M1 $(\mathrm{F}>3, \mathrm{p}<0.02)$; there was no significant

19 difference at Dancing Ladies. At Rio Bueno, M1 and Dancing Ladies only, mean size

20 had fallen significantly overall between 2002 and $2008(\mathrm{~F}>2, \mathrm{p}<0.05)$.

21 As the viability of small coral colonies over time can indicate reef resilience

22 (Loya, 1976; Connell, 1978), the annual changes in the colony numbers of the

23 smallest size class (0-250 $\mathrm{mm}^{2}$ surface area) each year from 2002-2008 was plotted

24 for all the non-branching species studied at the fringing reef sites, with examples

25 shown in Fig. 5 for Sidastrea siderea, Diploria labyrinthiformis, Porites astreoides, 
1 and Colpophyllia natans. There was a reduction in the smallest size class for all the

2 species at all the sites in 2006, with subsequent increases for all species at all sites in

32007 and 2008. Until 2006, there had been modest increases - or least no decreases -

4 in the numbers of the smallest size classes, with the exception of $D$. labyrinthiformis

5 at Rio Bueno, P. astreoides at Dancing Ladies, where the trends had decreased

6 slightly. Interestingly, in 2005, the year after hurricane Ivan, the most severe storm to

7 impact the reef sites over the study period, there was a slight reduction in the numbers

8 of the smallest size classes, particularly notable at Dairy Bull.

9 Dairy Bull reef was the site where studies resulted in the suggestion that there 10 had been a rapid phase-shift reversal on Jamaican reefs (Idjadi et al., 2006), and which

11 suffered a major loss of $A$. cervicornis in 2006 (Quinn and Kojis, 2008). Table 1 12 shows mean percentage cover of live coral, macroalgae and live Acropora species 13 along transects at Dairy Bull reef in 2005 (pre-bleaching), 2006, 2007 and 2008.

14 Cover of live coral, macroalgae and cover and live Acropora for 2005 and 2006 are 15 similar to figures reported by Quinn and Kojis (2008). While macroalgal cover 16 remained essentially unchanged in 2007 and 2008, there were increases in live coral 17 cover and live Acropora species in both 2007 and 2008. The majority of the increase 18 in coral is represented by increases in live A. cervicornis. This is illustrated in Fig. 6, 19 which shows complete bleaching of an A. cervicornis colony typical of Dairy Bull 20 reef after the mass bleaching event of 2005 and a large live colony of A. cervicornis 21 typical of Dairy Bull reef in 2008.

Coral growth rates are part of a demographic approach to monitoring coral 23 reef health (Smith et al., 2005), and Table 2 presents radial growth rates $\left(\mathrm{mm} \mathrm{yr}^{-1}\right)$ of

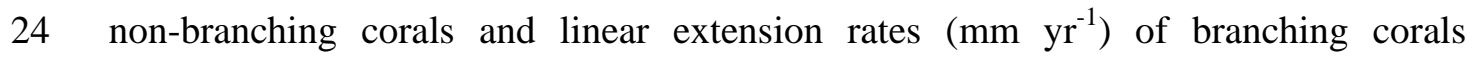


1 calculated on a annual basis and tabled from 2000-2003, 2003-2005, and 2005-2008

2 at all the sites studied. The growth rates are similar to those reported by Huston

3 (1985). There were few significant differences between the sites for each species

4 studied, or across the time period of the study. Where growth rates were higher, they

5 tended to be higher at Dairy Bull reef, but the differences were not significant. With

6 the increase of $D$. antillarum at Rio Bueno in recent years, clearing the macroalgae,

7 healthy A. palmata and A. cervicornis colonies have appeared at the Rio Bueno site

8 from 2006. At Dancing Ladies, a site with much macroalgal cover, A. cervicornis

9 colonies which were measurable from 2003-2005 had disappeared in 2006, possibly

10 as a result of the mass bleaching event, while at M1, a site with even greater

11 macroalgal cover, A. cervicornis colonies appeared which were measurable in 2008. 


\section{DISCUSSION}

Surveys of size-frequency distribution of corals are important in evaluating the condition of and changes in coral populations (Bak and Meesters, 1998; Meesters et al., 2001; Oigman-Pszczol and Creed, 2004). Here we have used a number of demographic tools to demonstrate the resilience of the fringing reefs around Discovery Bay, Jamaica, to a number of environmental stressors, in particular hurricanes and the mass bleaching event of 2005.

Hurricanes and tropical storms cause major damage and delayed mortality to corals (Knowlton et al., 1981; Done, 1999), as happened with hurricane Allen in 1980 to the fringing reefs in this study (Woodley et al., 1981). Alteration of substratum by storms reduces recruitment rates, as does the pre-emption of space by other corals or macroalgae (Connell, 1997; Connell et al., 1997). Storms have reduced the recruitment of non-branching corals both on these reefs (Crabbe et al., 2002) and on the Meso-American Barrier Reef off the coast of Belize (Crabbe et al., 2008), and it is interesting that in this study the numbers of colonies in the smallest size class of corals was lower after hurricane Ivan in 2004, although the reduction was insignificant relative to the reduction after the bleaching event of 2005. Bleaching of Acropora colonies generally led to mortality, with predation by the coral snail Coralliophilia abbreviata and the bearded fire worm Hermodice carunculata (Quinn and Kojis, 2008); this was often followed by invasion of filamentous algae.

It is the synergistic effect of multiple stressors that is damaging to reefs (Hughes and Connell, 1999; Mumby 1999; Gardner et al., 2003). The Jamaican reefs are subject to a number of both acute and chronic stressors, the last including overfishing and continuing coastal development, including the much-publicised development on land adjacent to Pear Tree Bottom reef and the resurfacing of the 
1 North Jamaican coastal highway (Westfield at al., 2008). On top of these came

2 tropical storms and the mass bleaching event during the study period. Fortunately,

3 there was little damage after the tropical storms, although in the year following

4 hurricane Ivan, which produced the highest winds in the area of the reef sites during

5 the study period, there was a reduction in the smallest size classes of the majority of

6 the non-branching corals studied, suggesting that the hurricane might have influenced

7 coral recruitment. Storms and hurricanes can influence sedimentation and turbidity,

8 which themselves have significant effects on coral growth (Gimour, 1999; Crabbe and

9 Carlin, 2007). While occasional storms can increase the survivorship of A. palmata

10 colonies (Lirman, 2003), increased freshwater inputs from storms reduces salinity,

11 and influences nutrient concentrations (Greenaway and Gordon-Smith, 2006; Mallela

12 and Perry, 2007) which in turn increase pre- and post-settlement mortality, changed

13 larval behaviour and substrate choice upon settlement (Vermeij et al., 2006).

14 Despite the multiple influences on the reef sites over the study period, the size

15 classes of the corals studied showed resilience to change. Interestingly, there were

16 differences between the sites, and between the species of corals. Dairy Bull, Rio

17 Bueno and Pear Tree Bottom showed a decrease in the numbers of smaller colonies

18 relative to a normal distribution for most species from 2002 to 2008 . The reef sites

19 which had the most macroalgal cover, Dancing Ladies and M1, showed fewer

20 changes in size class distribution through the study period, possibly because these

21 sites show large macroalgal cover (Crabbe, 2008). There were no significant

22 differences in fishing pressure between the sites. This study concentrates on size-

23 classes and growth rates; coral recruitment or survival (Smith et al., 2005) has not

24 been measured, although we have modelled coral recruitment at these sites (Crabbe et

25 al., 2002) and it has been measured in other studies (Quinn and Kojis, 2008). In this 
1 study we have not considered reef connectivities, relative colonisation rates or socio-

2 economic variables in reef resilience (Nyström et al., 2008).

3

4

By far the major acute influence on the reef sites was the mass bleaching event of late 2005. Mean size classes of most of the corals studied at the reef sites were reduced in 2006, and while there was considerable recovery by 2008 in mean size class of some species studied, there was no significant recovery to 2002 levels in mean size class for $C$. natans, $D$. labyrinthiformis, or $D$. strigosa colonies at most sites between 2006 and 2008, and in general mean size class was lower for these corals than in 2002. While there was a considerable drop in the smallest size class of all corals at all sites after the 2005 bleaching event, by 2008 numbers of colonies at all the sites had recovered considerably. In the coming years, if there are no major new catastrophic disturbances, these smaller colonies may result in increases in the mean size class to pre-2006 levels.

Interestingly, growth rates of both branching and non-branching corals showed similar values throughout the study period, with trends, not significant, for slightly higher values at Dairy Bull reef.

8 Diary Bull reef has for several years been the fringing reef with the most coral cover, with a benthic community similar to that of the 1970s (Huston ,1985), and it was the subject of the study which suggested a rapid phase-shift reversal (Idjadi et al., 2006). After the 2005 bleaching event there was a major loss of live coral cover, particularly of A. cervicornis (Quinn and Kojis, 2008; this study), and it is encouraging that both coral cover and the rapidly growing A. cervicornis colonies have returned to the reef at levels approaching pre-bleaching values. The influence of M. annularis colonies on the reef, acting as structural refugia (Idjadi et al., 2006), may 
1 have facilitated this recovery. Interestingly, we found a variety of clades of

2 zooxanthellae, including clade C, in corals at Dairy Bull reef (Crabbe and Carlin,

3 2007), and that may be a factor in their recovery (Stat et al., 2008).

4 Dairy Bull reef behaves somewhat like a successional niche (Pacala and Rees,

5 1998; Kinzig and Pacala, 2001), as late successional species are not the strongest

6 competitors, and the high population of $D$. antillarum at the site keep the macroalgae

7 in check. Despite continued overfishing (Hawkins and Roberts, 2004), there is a good

8 diversity of fish species, including herbivores such as Scaridae and Acanthuridae,

9 although fish sizes are small (usually $<100 \mathrm{~mm}$ ) (personal observation). Even at M1,

10 with one of the highest covers of macroalgae and no D. antillarum, we have seen that

11 A. cervicornis can form colonies after the major disturbance of the mass bleaching

12 event in 2005. Most reefs are open non-equilibium systems, (Connel, 1978) with

13 diversity maintained by disturbance and recruitment. While that may be true at the

14 macro- or landscape level, Dairy Bull reef, after the mass bleaching event, is

15 exhibiting some properties of niche diversification (Jackson, 1991; Pacala and Rees,

16 1998; Kinzig and Pacala, 2001).

17 What is apparent from this study is that despite the chronic and acute

18 disturbances between 2002 and 2008, demographic studies indicate good levels of

19 coral resilience on the fringing reefs around Discovery Bay in Jamaica. The bleaching

20 event of 2005 resulted in mass bleaching but relatively low levels of mortality (Quinn

21 and Kojis, 2008), unlike corals in the US Virgin islands where there was extensive

22 mortality (Miller et al., 2006; Whelen et al. 2007), possibly because of their greater

23 degree heating week values. The Jamaican reefs have suffered from long term

24 human-induced chronic stressors, such as overfishing and land development (Adger et

25 al., 2005; Jdalumbi et al., 2008; Mora, 2008; Mumby and Hasting, 2008). 
1 Unfortunately, previously successful efforts to engage the local fisherman in

2 controlling catches around Discovery Bay (Sary et al., 1997) have not been

3 maintained, and it may be that the development of a Discovery Bay Marine Park is the

4 only solution.

5

6 Acknowledgements

7 I thank the Royal Society and the Earthwatch Institute for funding, Mr. Anthony

8 Downes, Mr. Peter Gayle, Dr. George Warner, Dr. Norman Quinn and the staff of the

9 Discovery Bay Marine Laboratory for their invaluable help and assistance, Dr. Debbie

10 Lloyd for expert assistance in 2002, to many volunteers for their considerable help

11 underwater during this project, and the anonymous referees for their helpful

12 comments on the manuscript. This is publication number 765 from the Discovery

13 Bay Marine Laboratory. 
1

4

5 Aronson, R. B., Precht, W.F., 2001. Evolutionary paleoecology of Caribbean coral 6 reefs, in: W.D. Allmon, W.D., D.J. Bottjer, D.J. (Eds.), Evolutionary paleoecology:

7 the ecological context of macroevolutionary change. Columbia University Press,

$8 \quad$ New York USA, pp. 171-233.

9

20 Coles, S.L., Brown, E.K., 2007. Twenty-five years of change in coral coverage on a

21 hurricane impacted reef in Hawai'i: the importance of recruitment. Coral Reefs 26,

$22 \quad 705-717$.

24 Connell, J.H., 1978. Diversity in tropical rain forests and coral reefs. Science 199, $25 \quad$ 1302-1310. 
2 Connell, J. H., 1997. Disturbance and recovery of coral assemblages. Coral Reefs 16, 3 S101-S113.

4

5 Connell, J.H., Hughes, T.P., Wallace, C.C., 1997. A 30-year study of coral

6 abundance, recruitment, and disturbance at several scales in space and time.

$7 \quad$ Ecological Monographs 67, 461-488

8

9 Crabbe, M.J.C., Mendes, J.M., Warner, G.F., 2002. Lack of recruitment of non10 branching corals in Discovery Bay is linked to severe storms. Bulletin of Marine 11 Science 70, 939-945.

12

13 Crabbe, M.J.C., Smith, D.J., 2005. Sediment impacts on growth rates of Acropora and 14 Porites corals from fringing reefs of Sulawesi, Indonesia. Coral Reefs 24, 437-441. 15

16 Crabbe, M.J.C., 2007. Global warming and coral reefs: Modelling the effect of 17 temperature on Acropora palmata colony growth. Computational Biology and 18 Chemistry 31, 294-297.

20 Crabbe, M.J.C., Carlin, J.P., 2007. Industrial sedimentation lowers coral growth rates 21 in a turbid lagoon environment, Discovery Bay, Jamaica. International Journal of 22 Integrative Biology 1, 37-40.

24 Crabbe, M.J.C., 2008. Influence of Macroalgal Cover on Coral Colony Growth Rates 25 on Fringing Reefs of Discovery Bay, Jamaica. Open Marine Biology Journal 2, 1-6. 
2 Crabbe, M.J.C., Martinez, E., Garcia, C., Chub, J., Castro, L., Guy, J., 2008. Growth

3 modelling indicates hurricanes and severe storms are linked to low coral recruitment

4 in the Caribbean. Marine Environmental Research 65, 364-368.

6 Crabbe, M.J.C., Martinez, E., Garcia, C., Chub, J., Castro, L., Guy, J., 2009.

7 Identifying management needs for coral reef ecosystems. Sustainability: Science, $8 \quad$ Practice \& Policy. In the Press.

9

10 D’Elia, C.F., Webb, K.L., Porter J.W., 1981. Nitrate-rich groundwater inputs to 11 Discovery Bay, Jamaica: a significant source of $\mathrm{N}$ to local reefs? Bulletin of Marine 12 Science 31, 903-910.

13

14 Done, T. J., 1999. Coral community adaptability to environmental change at the scales 15 of regions, reefs and reef zones. American Zoologist 39, 66-79.

17 Foster, N.L., Baums, I.B., Mumby, P.J., 2007. Sexual vs. asexual reproduction in an 18 ecosystem engineer: the massive coral Montastrea annularis. Journal of Animal 19 Ecology 76, 384-391.

21 Gardner, T.A., Côté, I.M., Gill, J.A., Grant, A., Watkinson, A.R., 2003. Long-term

22 region-wide declines in Caribbean corals. Science 301, 958-960. 
1 Gimour, J.P. 1999. Experimental investigation into the effects of suspended sediment

2 on fertilisation, larval survival and settlement in scleractinian coral. Marine Biology

3 135, 451-462.

4

5 Greenaway, A.M., Gordon-Smith, D.-A., 2006. The effects of rainfall on the

6 distribution of inorganic nitrogen and phosphorus in Discovery Bay, Jamaica.

$7 \quad$ Limnology and Oceanography 51, 2206-2220.

8

9 Grimsditch, G.D., Salm, R.V., 2006. Coral reef resilience and resistance to bleaching. 10 IUCN/The Nature Conservancy. Gland, Switzerland. 52pp.

11

12

14

15

16

17

18 Hughes, T.P., Connell, J.H., 1999. Multiple stressors on coral reefs:a long term 19 perspective. Limnology and Oceanography 44, 932-940.

20

21 Hughes, T.P., Tanner, J.E., 2000. Recruitment failure, life histories and long-term

22 decline of Caribbean corals. Ecology 81, 2250-2263.

24 Huston, M., 1985. Variation of coral growth rates with depth at Discovery Bay, 25 Jamaica. Coral Reefs 4, 19-25. 
2 Idjadi, J.A., Lee, S.C., Bruno, J.F., Precht, W.F., Allen-Requa, L., Edmunds, P.J.,

3 2006. Rapid phase-shift reversal on a Jamaican coral reef. Coral Reefs 25, 209-211.

4 Jackson, J.B.C., 1991. Adaptation and diversity of reef corals. BioScience 41, 4755482.

6

7 Jackson, J.B.C., 1997. Reefs since Columbus. Proceedings of the $8^{\text {th }}$. International 8 Coral Reef Symposium. 1, 97-106.

9

10 Jdalumbi, S.R., Mcleod, K.L., Grunbaum, D., 2008. Ecosystems in action: Lessons

11 from marine ecology about recovery, resistance and reversibility. BioScience 58, 331242.

13

14 Jones, L., Warner, G., Linton, D., Alcolado, P., Claro-Madruga, R., Clerveaux, W., 15 Estrada, R., Fisher, T., Lockhart, K., Pardee, M., Pitt, J., Scheltin, C., Wild, R., 2004. 16 Status of coral reefs in the northern Caribbean and western Atlantic node of GCRNM, 17 in: Wilkinson, C. (Ed.), Status of coral reefs of the world : 2004 Vol. 2. Global Coral 18 Reef Monitoring Network, and Reef and Rainforest Research Centre, Townsville, 19 Australia, pp. 451-472.

21 Jones, L., Alcolado, P.M., Cala, Y., Cobián, D., Coelho, V., Hernández, A., Jones, 22 R., Mallela, J., Manfrino, C. 2008. The effects of coral bleaching in the northern 23 Caribbean and western Atlantic. In: Wilkinson, C., Souter, D. (Eds.), Status of 24 Caribbean Coral Reefs after Bleaching and Hurricanes in 2005. Global Coral Reef 
1 Monitoring Network, and Reef and Rainforest Research Centre, Townsville,

2 Australia, pp. 73-83.

3

4 Kinzig, A.P., Pacala, S.W., 2001. Successional biodiversity and ecosystem

5 functioning, in: Kinzig, A.P., Pacala, S.W., Tilman, D. (Eds.), The functional

6 consequences of biodiversity. Princeton University Press, Princeton, USA, pp. 175-

7212.

8

9 Knowlton, N., Lang, J.C., Rooney, M.C., Clifford, P., 1981. Evidence for delayed

10 mortality in hurricane-damaged Jamaican staghorn corals. Nature 294, 251-252.

12 Lirman, D., 2003. A simulation model of the population dynamics of the branching 13 coral Acropora palmata - effects of storm intensity and frequency. Ecological

14 Modelling 161, 169-182.

15

16 Loya, Y., 1976. Skeletal regeneration in a Red Sea scleractinian coral population.

17 Nature 261, 490-491.

18

19 Mallela, J., Perry, C.T., 2007. Calcium carbonate budgets for two coral reefs affected 20 by different terrestrial runoff regimes, Rio Bueno, Jamaica. Coral Reefs 26, 129-145.

22 Meesters, E.H.I., Hilterman, M., Kardinaal, E., Keetman, M., de Vries, M., Bak, 23 R.P.M., 2001. Colony size-frequency distributions of scleractinian coral populations: 24 spatial and interspecific variation. Marine Ecology Progress Series 209, 43-54. 
1 Miller, J.R., Waara, R., Muller, E., Rogers, C., 2006. Coral bleaching and disease

2 combine to cause extensive mortality on reefs in US Virgin islands. Coral Reefs 25, 3418.

4

5 Mora, C., 2008. A clear human footprint in the coral reefs of the Caribbean.

$6 \quad$ Proceedings of the Royal Society B- Biological Sciences 275, 767-773.

7

8 Mumby, P.J., 1999. Bleaching and hurricane disturbances to populations of coral

9 recruits in Belize. Marine Ecology Progress Series 190, 27-35.

11 Mumby, P.J., Hastings, A., 2008. The impact of ecosystem connectivity on coral 12 reef resilience. Journal of Applied Ecology 45, 854-862.

13

14 Mumby, P.J., Hastings, A., Edwards, H.J., 2007. Thresholds and the resilience of 15 Caribbean coral reefs. Nature 450, 98-101.

16

17 Nyström, M., Graham, N.A.J., Lokrantz, J., Norström, A.V., 2008. Capturing the 18 cornerstones or coral reef resilience: linking theory to practice. Coral Reefs 27, 79519809.

20

21 Oigman-Pszczol., S.S., Creed, J.C., 2004. Size structure and spatial distribution of 22 the corals Mussismilia hispida and Siderastrea stellata (Scleractinia) at Armação 23 dos Búzios, Brazil. Bulletin of Marine Science 74, 433-448. 
1 Pacala, S.W., Rees, M., 1998. Models suggesting field experiments to test two

2 hypotheses explaining successional diversity. American Naturalist 152, 729-737.

3

4 Quinn, N.J., Kojis, B.L., 2008. The recent collapse of a rapid phase-shift reversal on a

5 Jamaican north coast reef after the 2005 bleaching event. International Journal of

$6 \quad$ Tropical Biology 56 (suppl. 1), 149-159.

7

8 Sary, Z., Oxenford, H.A., Woodley, J.D., 1997. Effects of an increase in trap mesh

9 size on an over-exploited coral reef fishery at Discovery Bay, Jamaica. Marine

10 Ecology Progress Series 154,107-120.

12 Smith, L.D., Devlin, M., Haynes, D., Gilmour, J.P., 2005. A demographic approach to 13 monitoring the health of coral reefs. Marine Pollution Bulletin 51, 399-407.

14

15 Soong, K., 1993. Colony size as species character in massive reef corals. Coral Reefs $16 \quad 12,77-83$.

17

18 Stat, M., Morris, E., Gates, R.D., 2008. Functional diversity in coral-dinoflagellate

19 symbiosis. Proceedings of the National Academy of Sciences USA 105, 9256-9261.

21 Vermeij, M.J.A., Fogarty, N.D., Miller, M.W., 2006. Pelagic conditions affect larval

22 behavior, survival, and settlement patterns in the Caribbean coral Montastrea 23 faveolata. Marine Ecology Progress Series 310, 119-128. 
1 Westfield, I., Dworkin, S., Bonem, R., Lane, E., 2008. Identification of sediment

2 sources using geochemical fingerprinting at Pear tree Bottom Reef, Runaway Bay,

3 Jamaica. Abstracts of the $11^{\text {th }}$ International Coral Reef Society, p. 137.

4

5 Whelan, K. R. T., Miller, J., Sanchez, O., Patterson, M., 2007. Impact of the 2005

6 coral bleaching event on Porites porites and Colpophyllia natans at Tektite Reef, US

7 Virgin Islands. Coral Reefs 26, 689-693.

8

9 Woodley, J.D., Chornesky, E.A., Clifford, P.A., Jackson, J.B.C., Kaufman, L.S., 10 Knowlton, N., Lang, J.C., Pearson, M.P., Porter, J.W., Rooney, M.C., Rylaarsdam, 11 K.W., Tunnicliffe, V.J., Wahle, C.M., Wulff, J.L., Curtis, A.S.G., Dallmeyer, M.D., 12 Jupp, B.P., Koehl, M.A.R., Neigel, J., Sides, E.M., 1981. Hurricane Allen’s impact on 13 Jamaican coral reefs. Science, 214, 749-755.

14

15 Zar, J.H., 1999. Biostatistical Analysis. Fourth edition. Prentice-Hall, New Jersey, p. $16 \quad 663$. 


\section{Legends to Figures}

2 Fig. 1. Satellite image showing the location of fringing reef sites in this study (Rio

3 Bueno, M1, Dancing Ladies, Dairy Bull and Pear Tree Bottom) around Discovery

4 Bay, Jamaica. DBML, Discovery Bay Marine Laboratory. The horizontal line shows $5 \quad 1 \mathrm{~km}$ distance. See text for GPS coordinates.

6

7 Fig. 2.Hurricane tracks impacting the Jamaican fringing reefs around Discovery Bay

8

9 Fig. 3. Size-frequency distribution of colonies in 2002 (a, c, e, g) and in 2008 (b, d, f, 10

h) of: Sidastrea siderea (a,b); Diploria labyrinthiformis (c,d); Porites astreoides (e, f); and Colpophyllia natans (g,h) at Rio Bueno (RB), M1 (M1), Dancing Ladies (DL), Dairy Bull (DB), and Pear Tree Bottom (PTB). Skewness (sk) values are discussed in the text.

Fig. 4. Mean size classes in 2002, in 2006 and in 2008 of: Sidastrea siderea (a); Diploria labyrinthiformis (b); Porites astreoides (c); and Colpophyllia natans (d) at Rio Bueno (RB), M1 (M1), Dancing Ladies (DL), Dairy Bull (DB), and Pear Tree Bottom (PTB). Bar lines represent standard errors; probability values are discussed in the text.

Fig. 5. Graphs of annual changes in the colony numbers of the smallest size class (0$250 \mathrm{~mm}^{2}$ surface area) from 2000-2008 for: Sidastrea siderea (a); Diploria labyrinthiformis (b); Porites astreoides (c); and Colpophyllia natans (d) at Rio Bueno (RB), M1 (M1), Dancing Ladies (DL), Dairy Bull (DB), and Pear Tree Bottom (PTB). 
$1 \quad$ Fig. 1

2

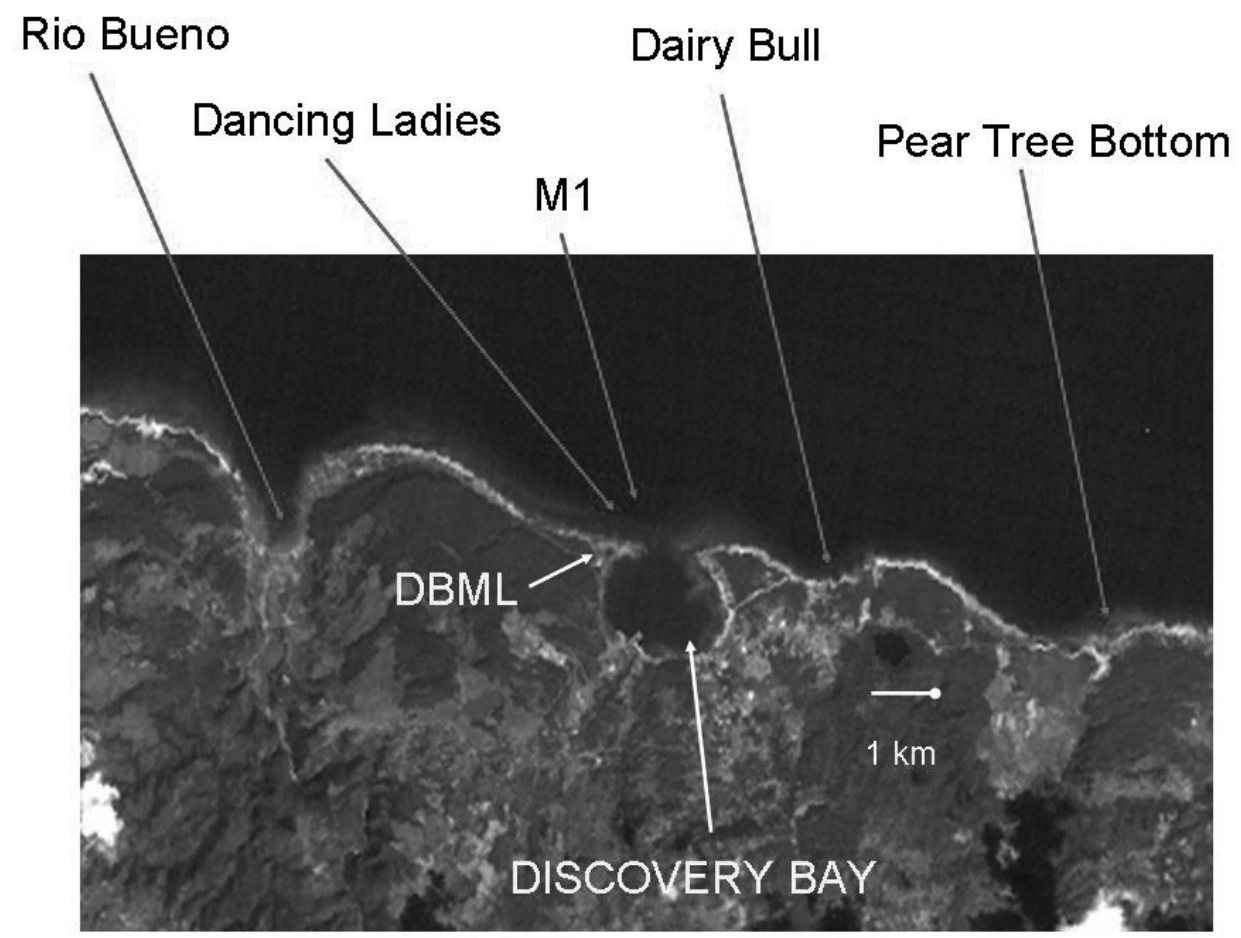




\section{ACCEPTED MANUSCRIPT}

$1 \quad$ Fig. 2

2

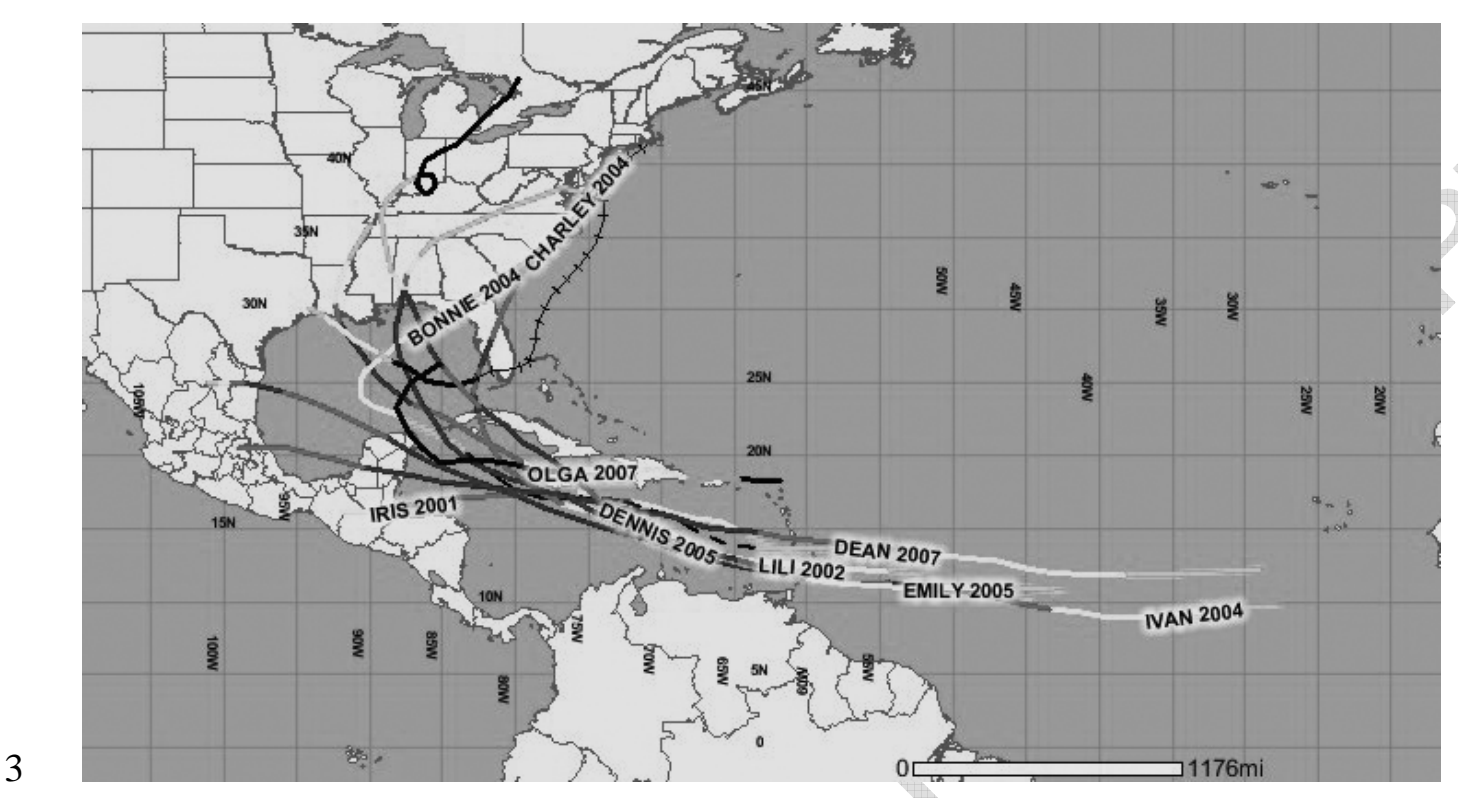

3

\section{2}


Fig.3

2

3

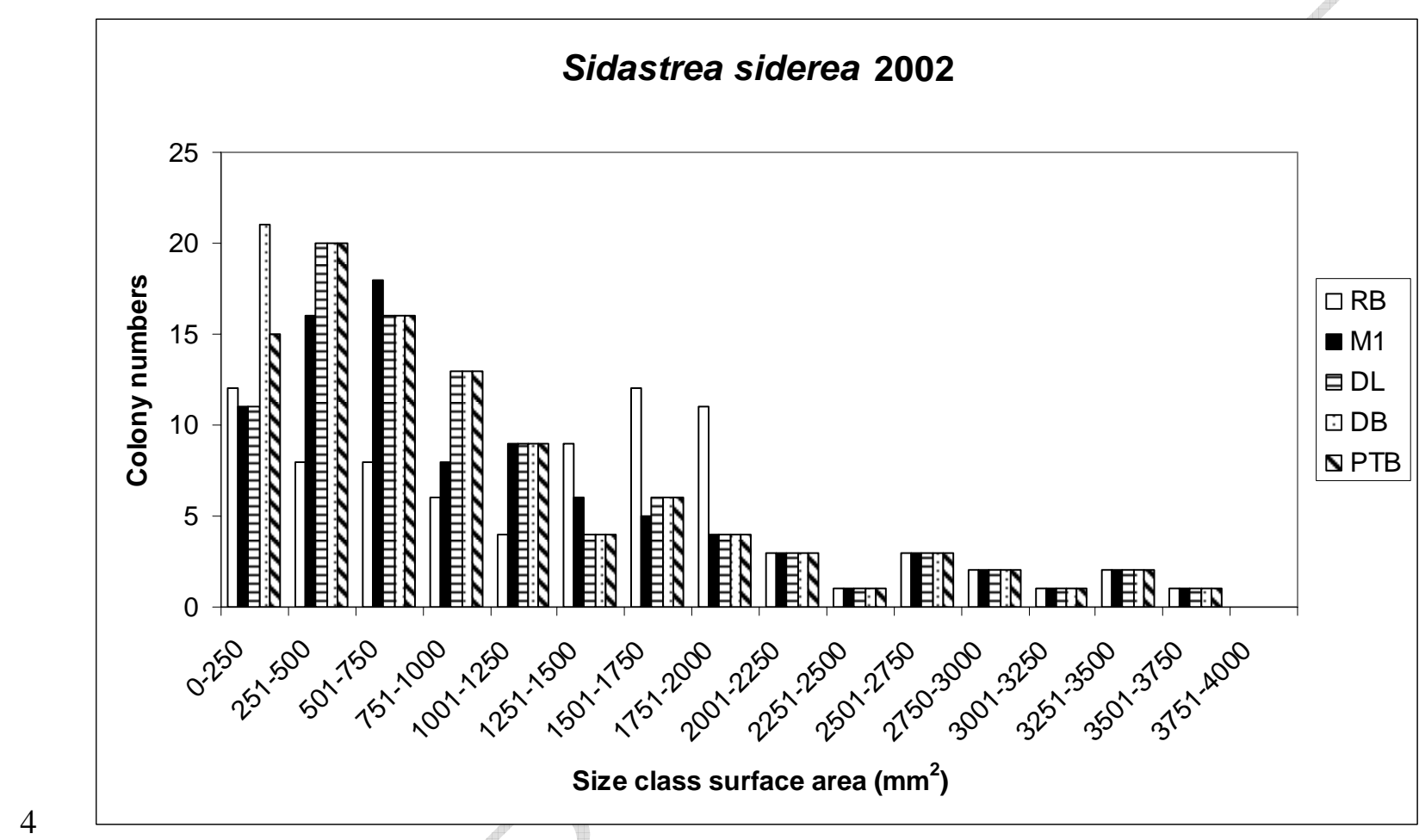

5 Fig. 3a.

\section{Sidastrea siderea 2008}

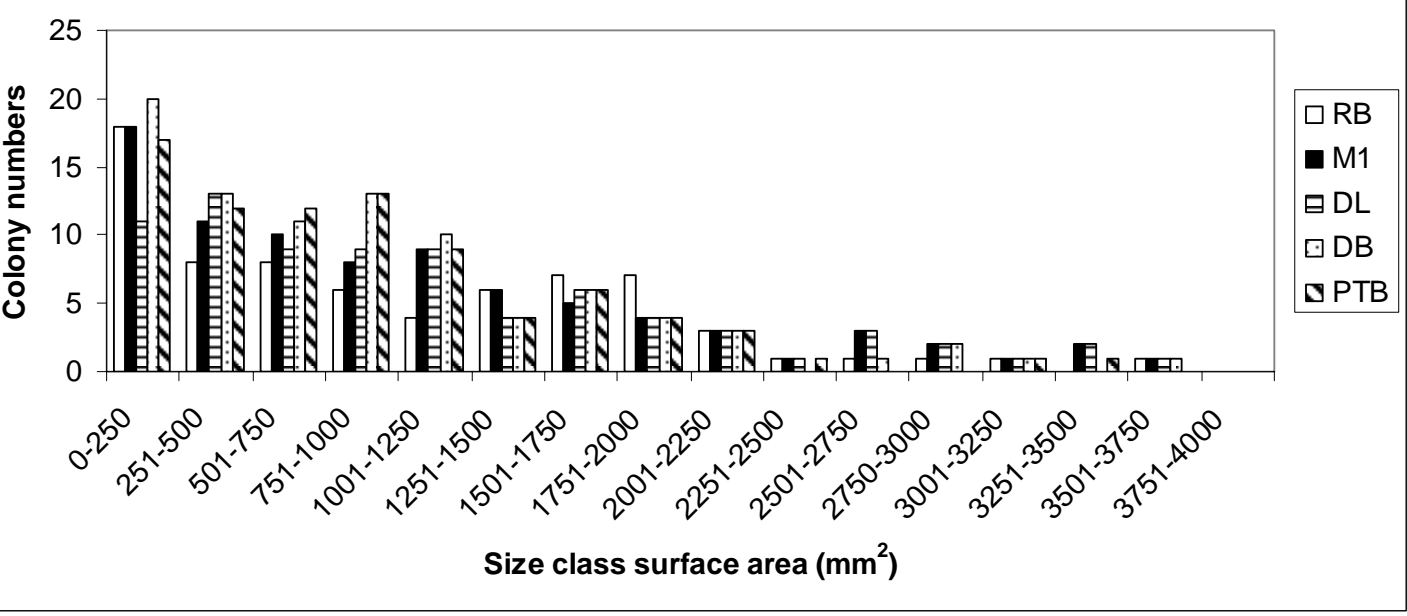

Fig 3b. 


\section{ACCEPTED MANUSCRIPT}

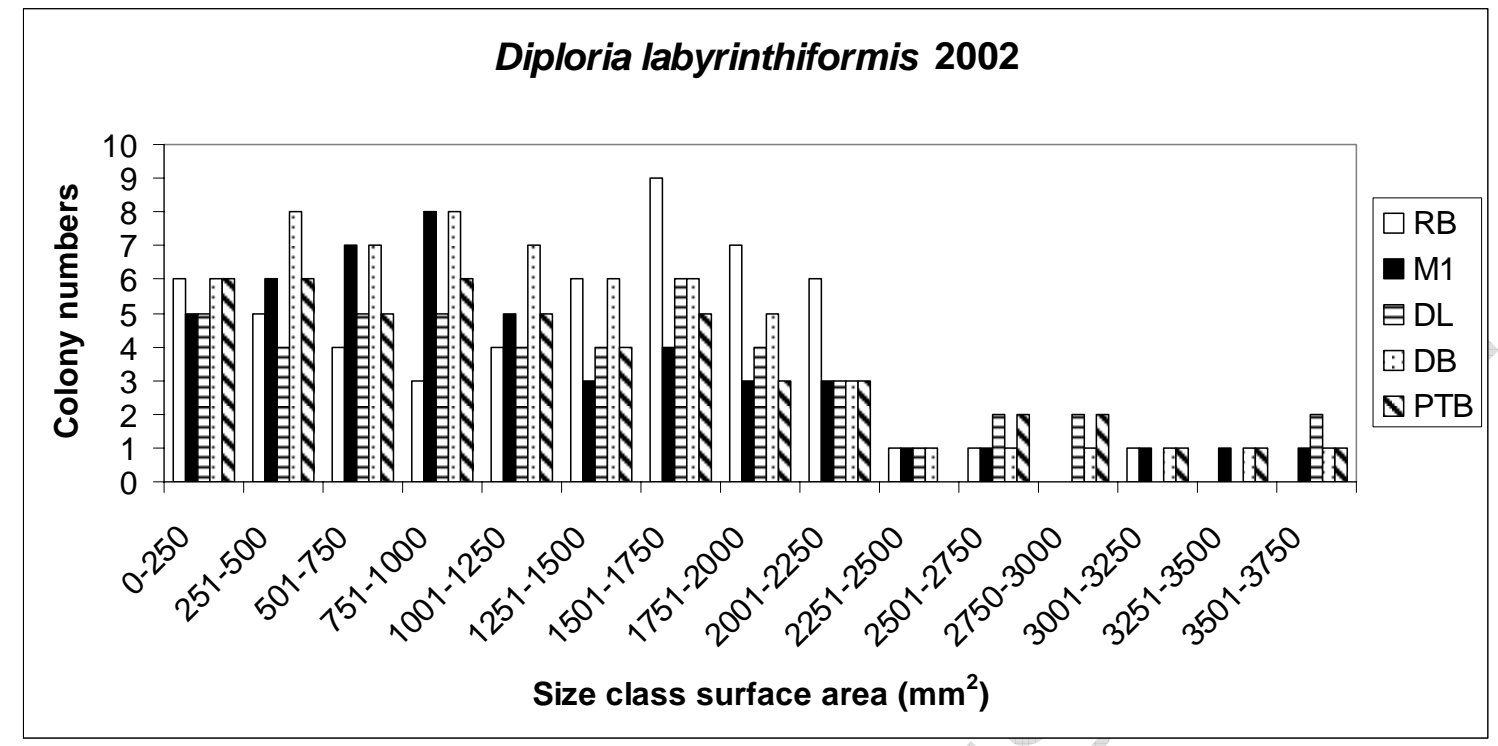

2

3 Fig. 3c.

4

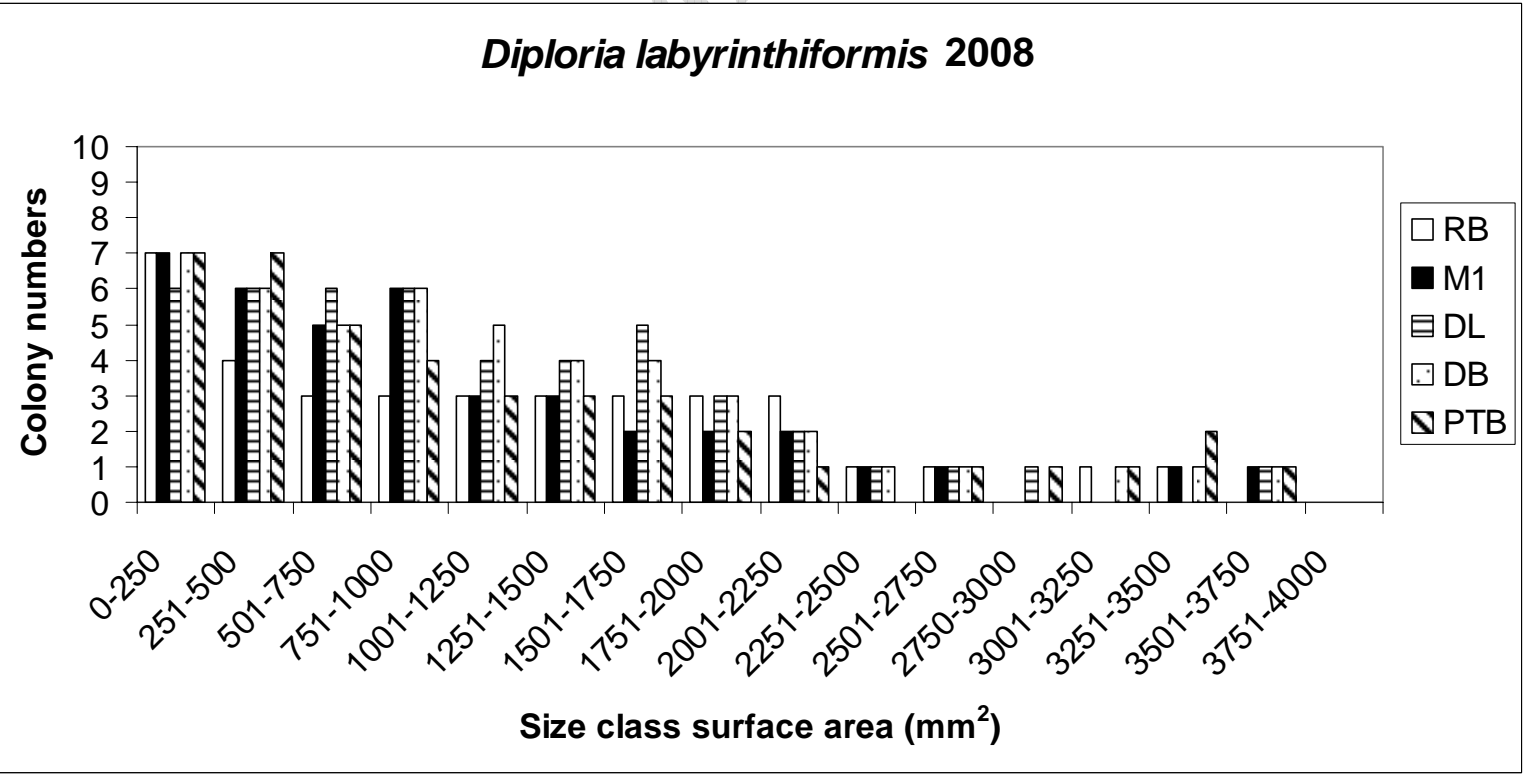

6

7 Fig. 3d. 


\section{ACCEPTED MANUSCRIPT}

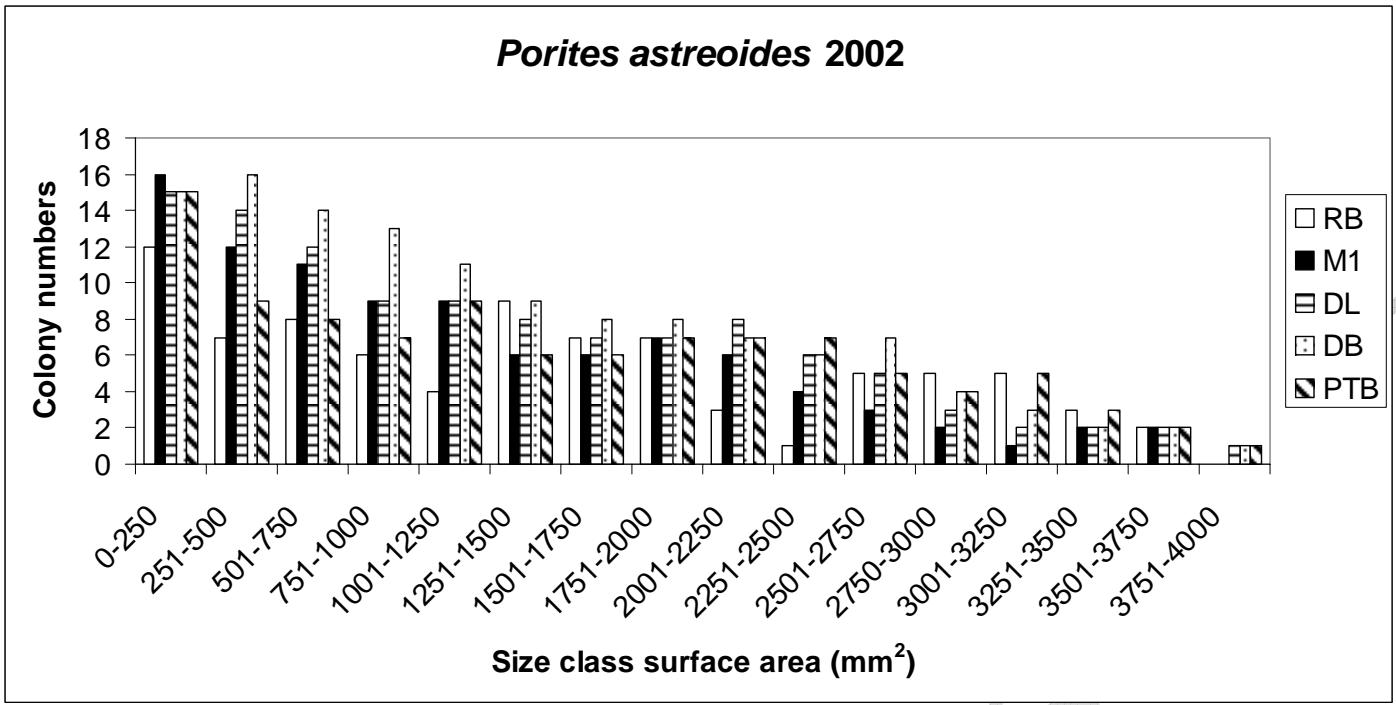

2

3 Fig. 3e.

4

\section{Porites astreoides 2008}
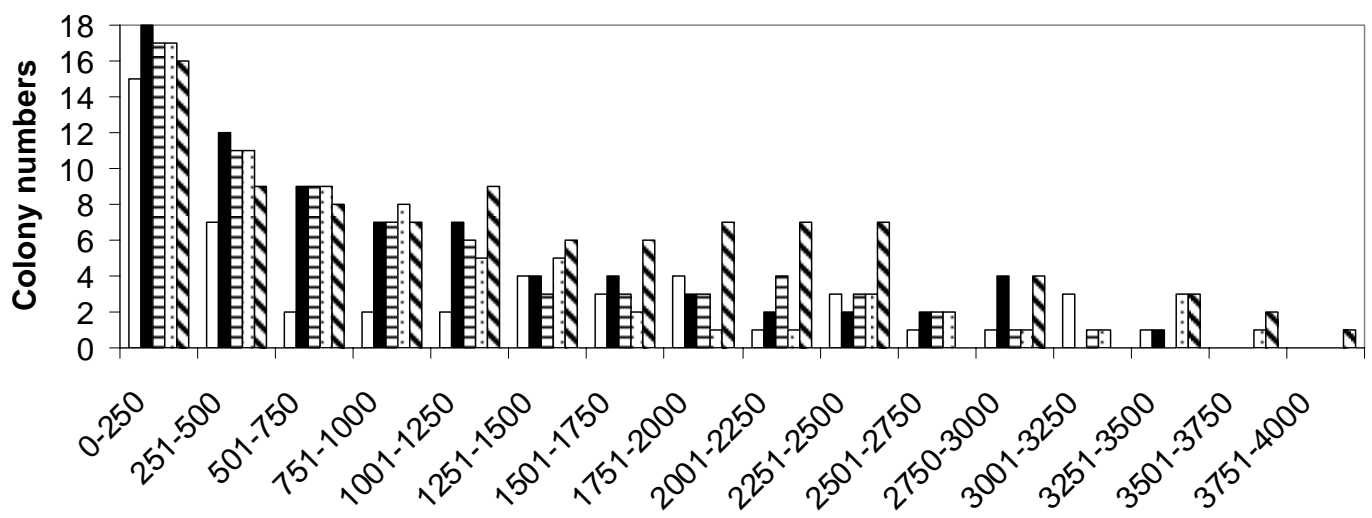

Size class surface area $\left(\mathrm{mm}^{2}\right)$

5

6

$7 \quad$ Fig. 3f.

8 


\section{ACCEPTED MANUSCRIPT}

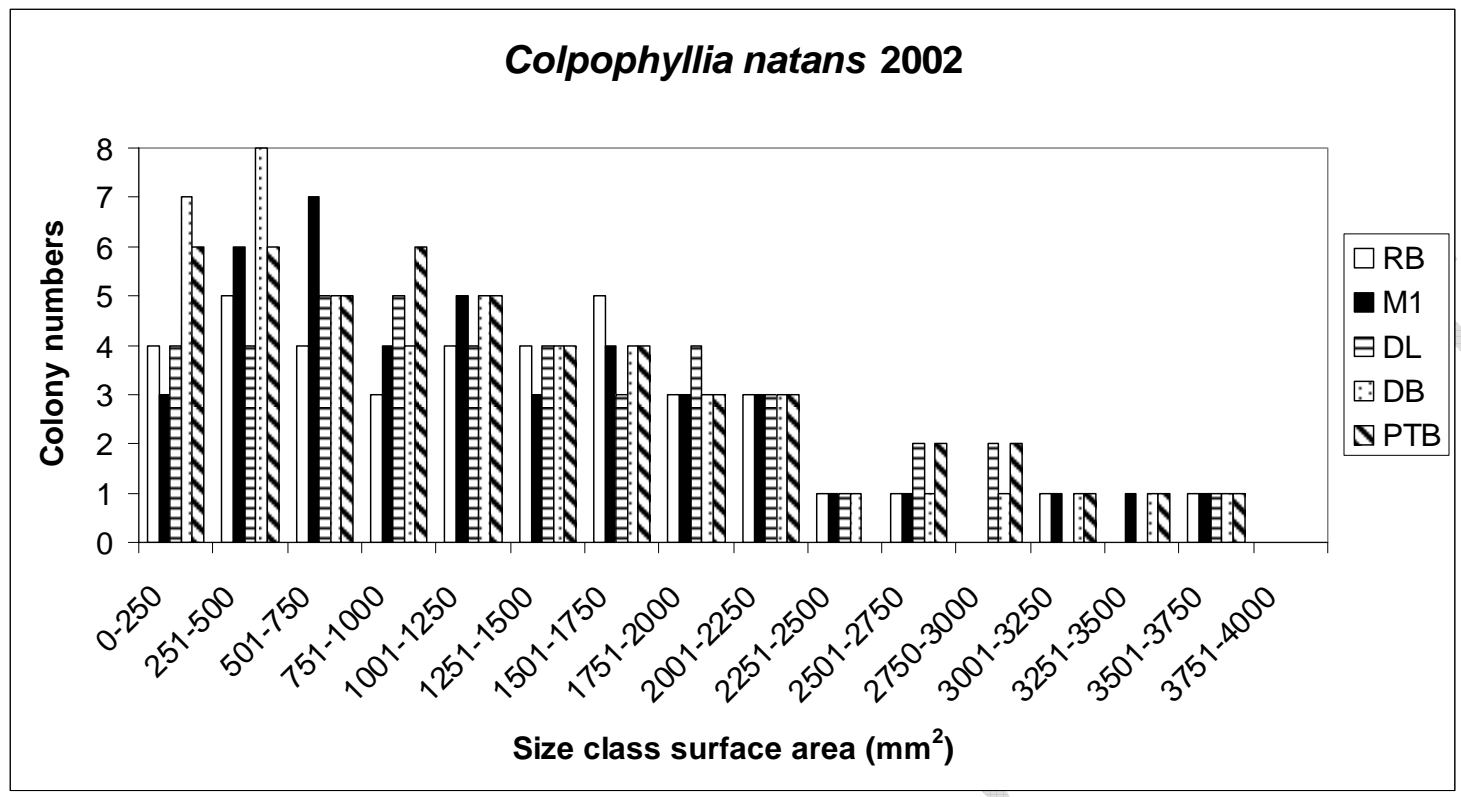

2

$3 \quad$ Fig. 3g.

4

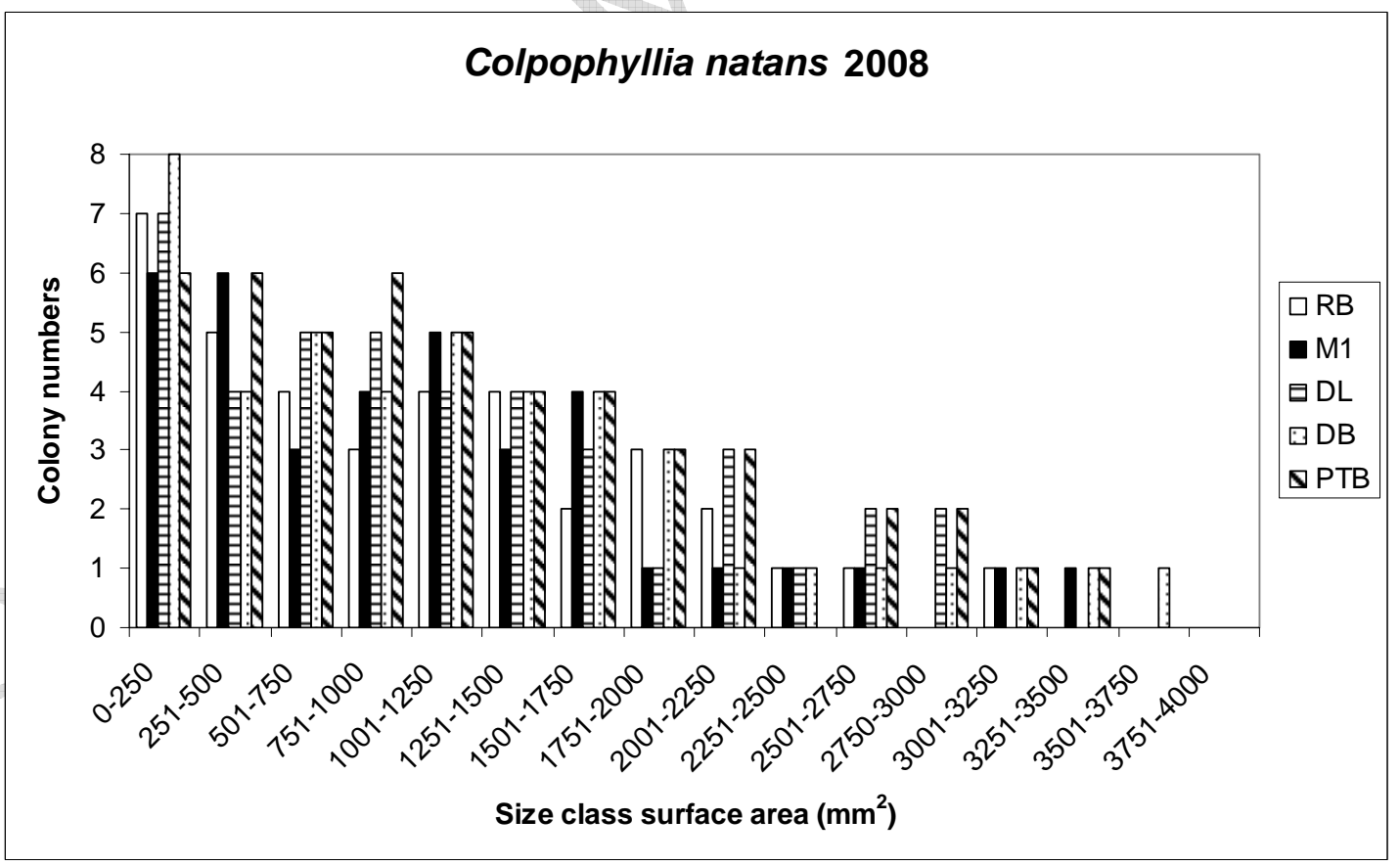

6

$7 \quad$ Fig. 3h.

8 
$1 \quad$ Fig. 4

2

3

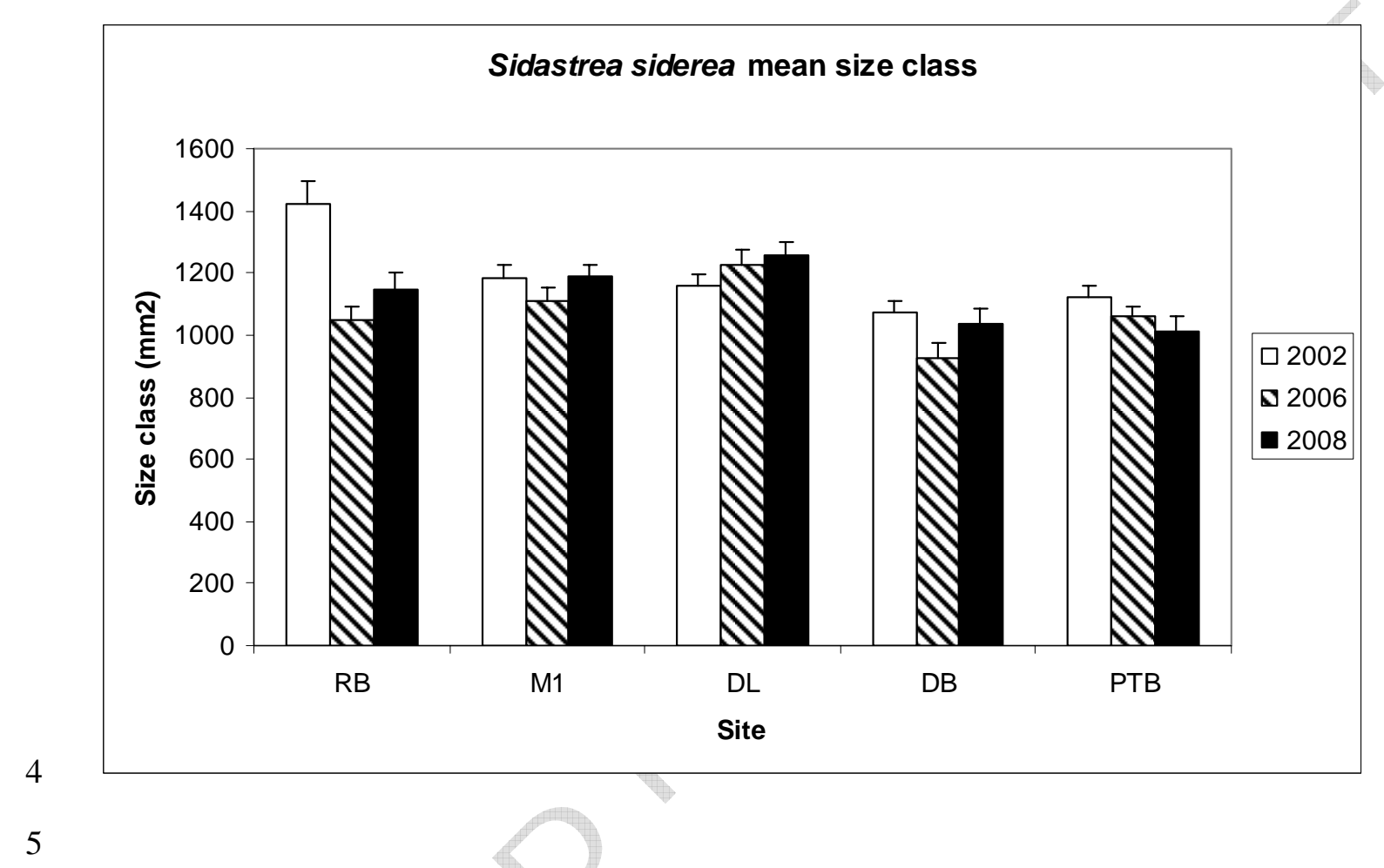

6 Fig. 4a.

7 


\section{Diploria labyrinthiformis mean size class}

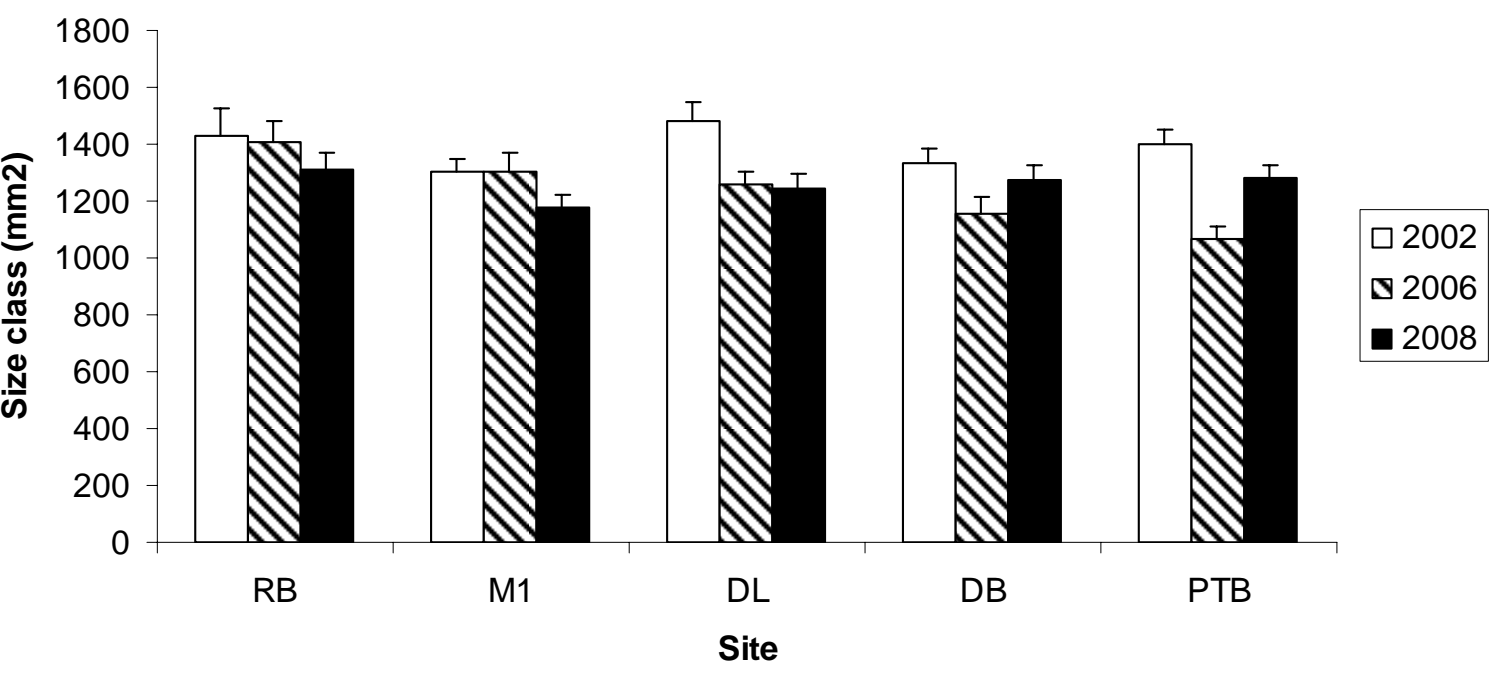

2

3 Fig. 4b.

4

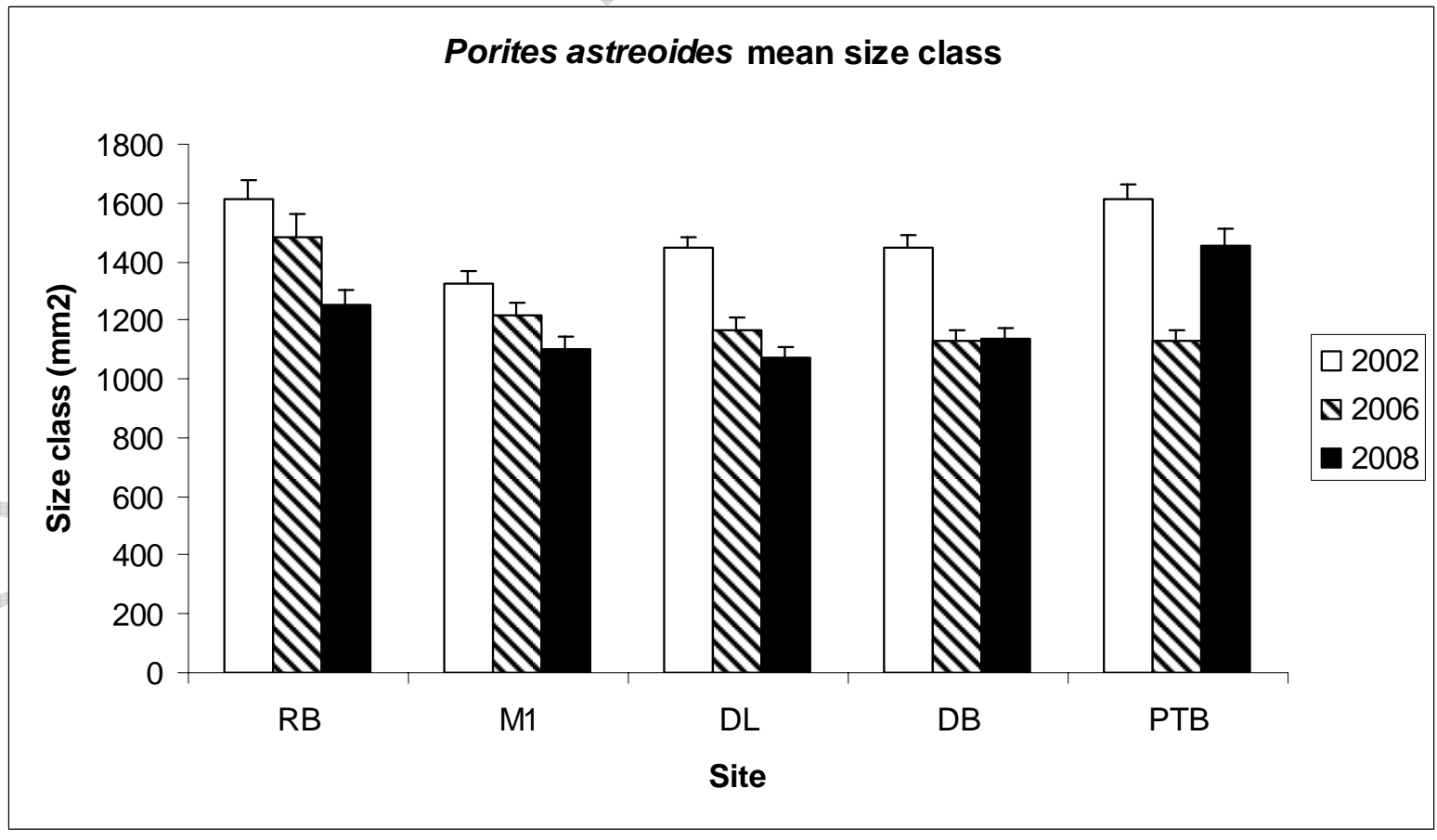

6 Fig. 4c. 


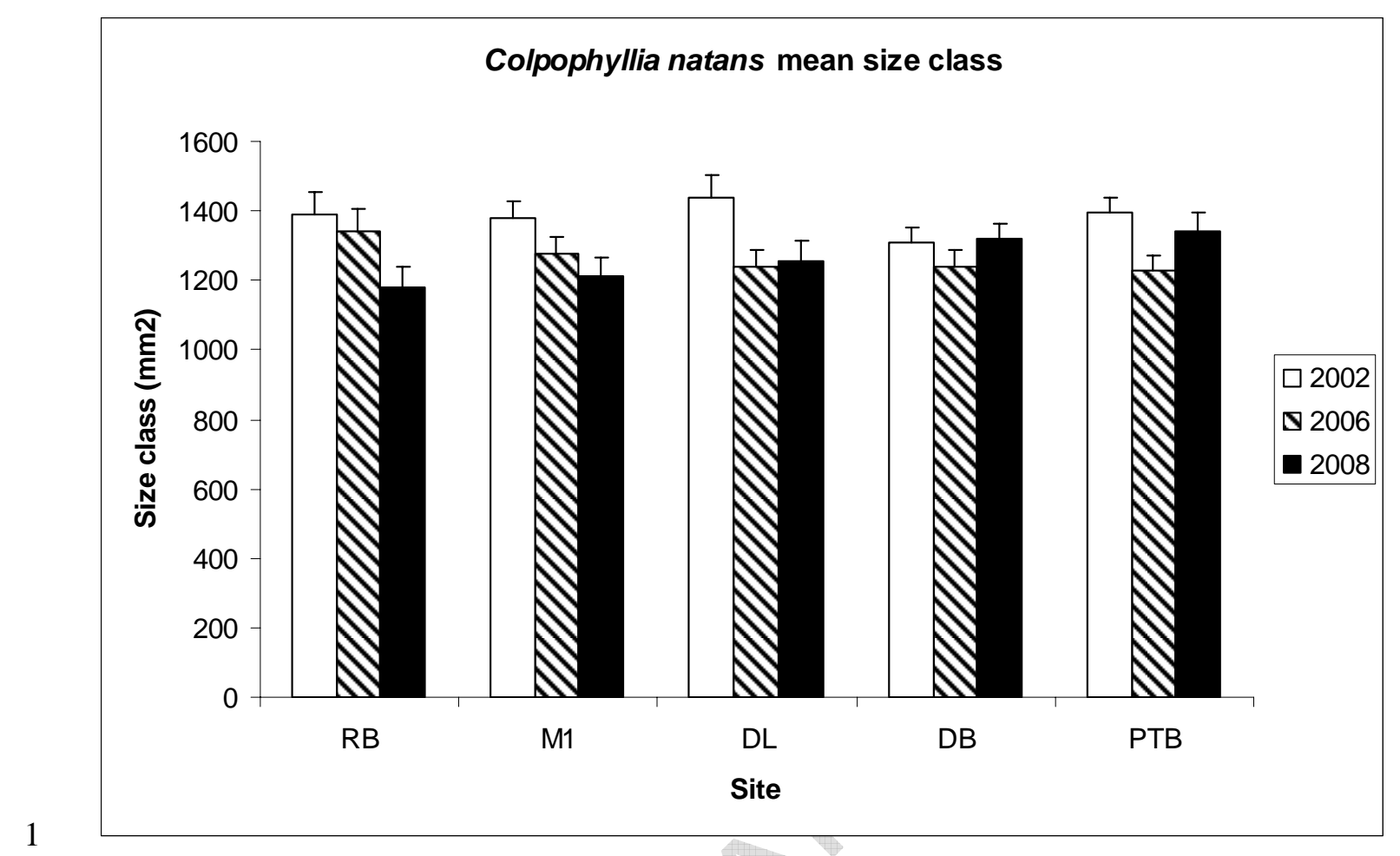

2 Fig. 4d. 


\section{ACCEPTED MANUSCRIPT}

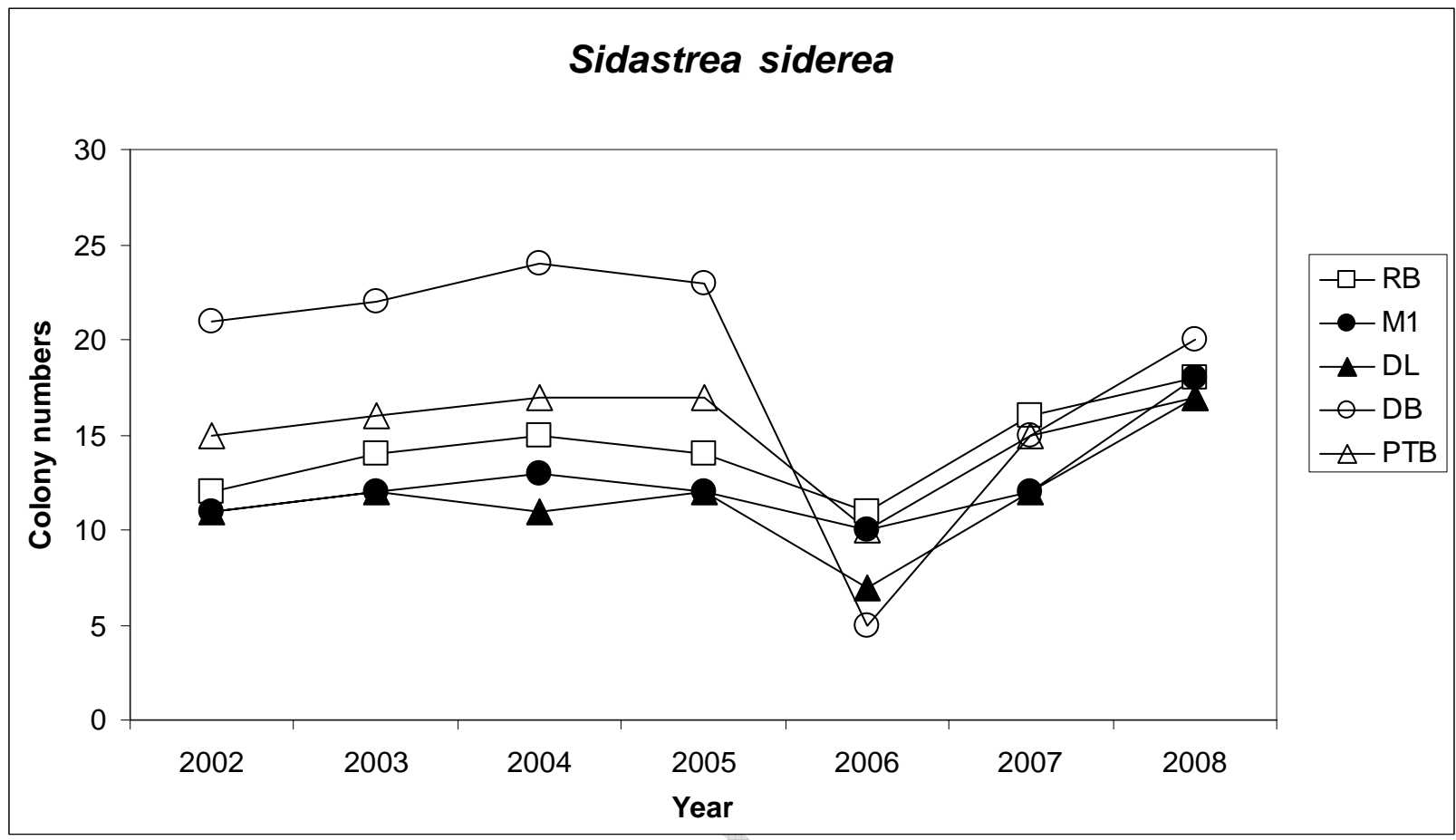

2

3 Fig. 5a.

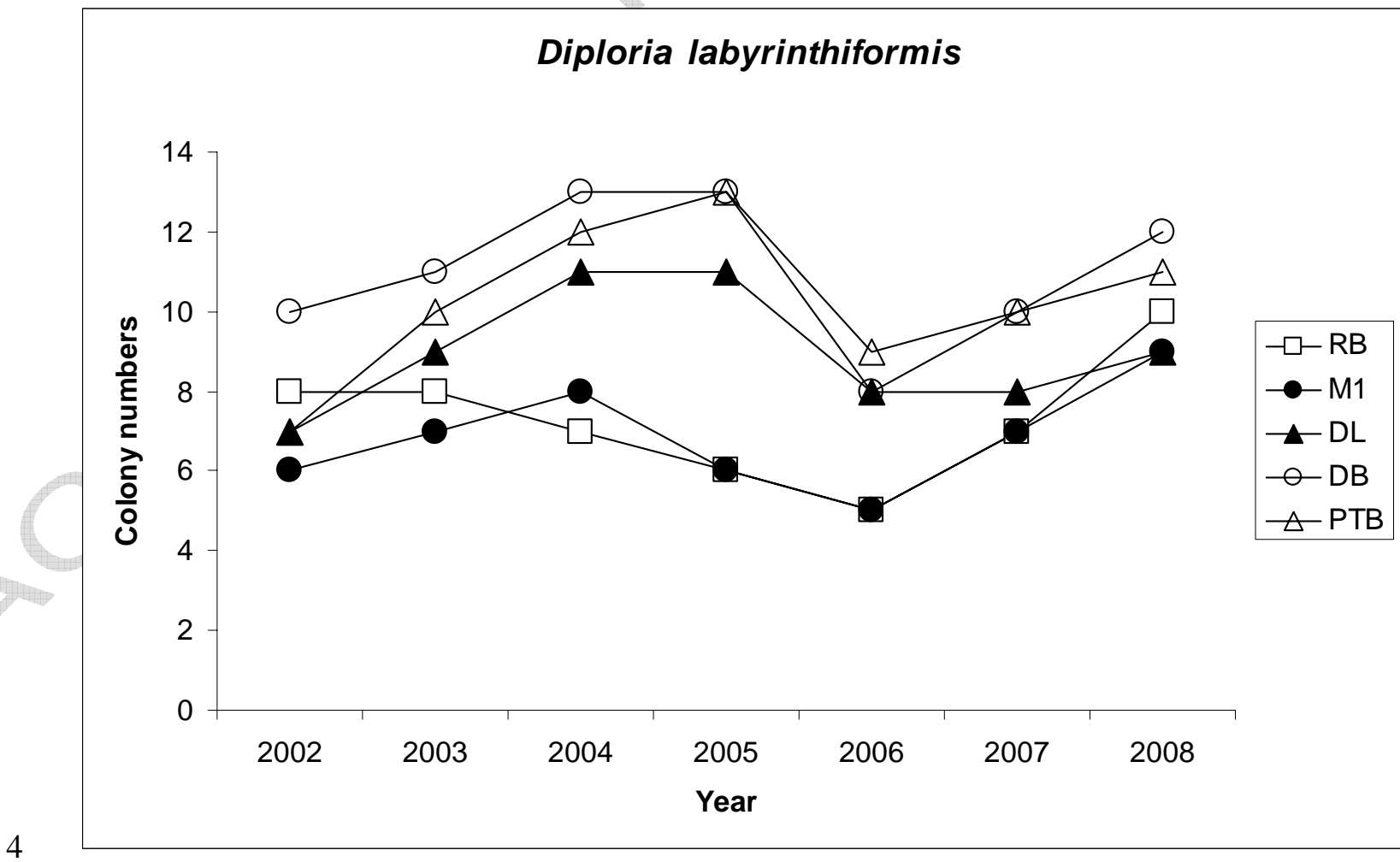

$5 \quad$ Fig. 5b. 


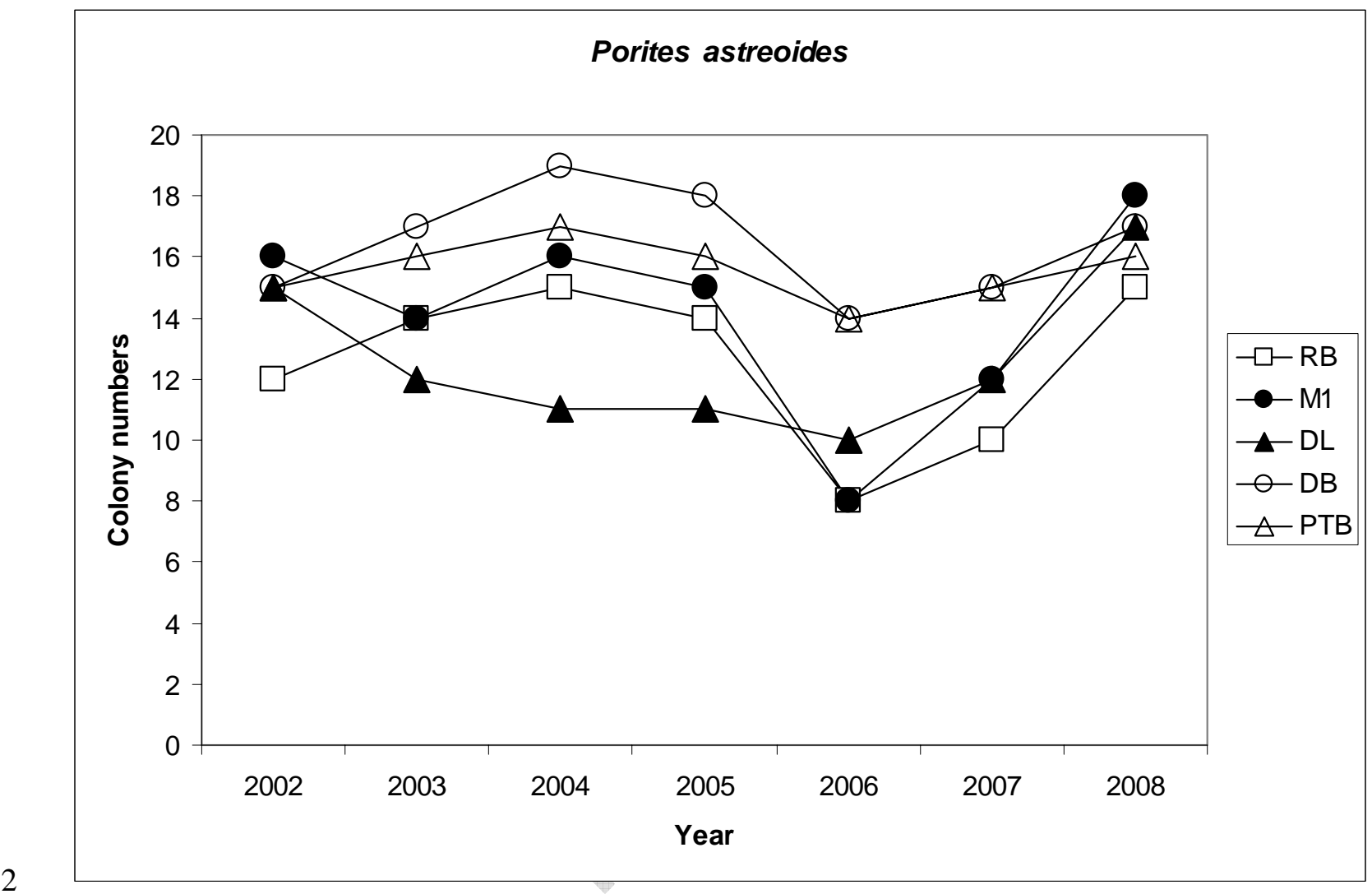

3 Fig. 5c. 


\section{ACCEPTED MANUSCRIPT}

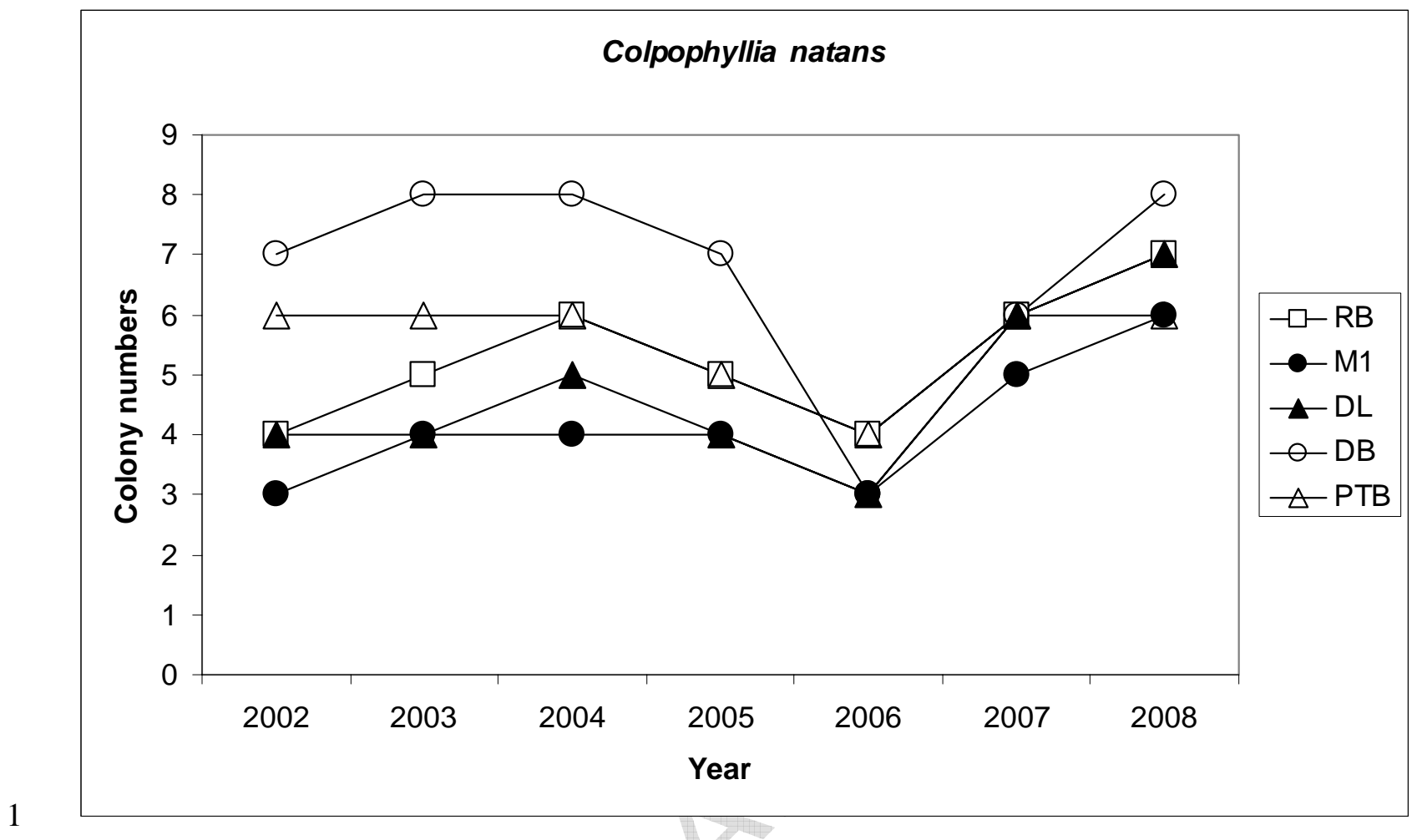

2 Fig. 5d. 
1 Table 1. Mean percentage cover of live coral, macroalgae and live Acropora species

2 along transects at Dairy Bull, in 2005 (pre-bleaching), 2006, 2007 and 2008. Values

3 are \pm standard errors.

4

5 Year $\quad$ Live coral (\%) $\quad$ Macroalgae (\%) $\quad$ Acropora species (\%)

6

$7 \quad 2005$

$46 \pm 8$

$8 \pm 3$

$33 \pm 5$

82006

$13 \pm 5$

$6 \pm 3$

$2 \pm 2$

$9 \quad 2007$

$20 \pm 9$

$6 \pm 3$

$10 \pm 4$

$10 \quad 2008$

$31 \pm 7$

$5 \pm 2$

$22 \pm 7$

11

12

13

14 